\title{
Helâl ve Haramlarla İlgili Kaide ve İlkeler
}

\author{
Dr. Yüksel ÇAYIROĞLU*
}

Atıf / @)- Çayıroğlu, Y. (2018). Helâl ve Haramlarla İlgili Kaide ve İlkeler, Çukurova Üniversitesi Illahiyat Fakültesi Dergisi, 18 (1), 597-633.

Öz- İslâm'da, şerî hükümlerin önemli bir kısmını helâl ve haramlar oluşturur. Zira inanç ve ahlâka dair mevzuların yanında fıkhın alt bölümlerini oluşturan ibadetler, muameleler ve cezalara dair pek çok yasak getirilmiştir. Dolayısıyla helâl ve haramın temel mantığı kavranmadan ve bu konuda geçerli olan ilke ve prensipler bilinmeden, şeriatın doğru bilinip anlaşılması mümkün olmadığı gibi, ortaya çıkan güncel problemler hakkında isabetli hükümlerin verilmesi de mümkün olmayacaktır. Bunun önemli bir sebebi, helâl ve haramlarla ilgili kâidelerin, kanuna karşı hile, hükümlerin kaynakları, vesile ve maksatlar, ihtiyat, şüphe, niyet, zarar, maslahat, zaruret ve taabbudîlik gibi fıkhın temel konularıly olan yakın ilişkisidir. Bu makalede, helâl ve haram hükümlerine hâkim olan başlıca küllî kâide ve prensipler ele alınmıştır. Bu makalede ele alınan kâide ve prensipler şunlardır: Helâl ve haram kılma yetkisi Allah'a aittir; eşyada asıl olan ibahadır; menfaatlerde helâllik, zararlarda ise haramlık asıldır; haramı meşru göstermek için hileye başvurmak da haramdır; harama götüren vesileler de haramdır; harama düşmemek için şüpheli şeyler terkedilmelidir; helal ve haram bir arada bulunduğunda haramlık yönü tercih edilir; iyi niyet haramları mubah kılmaz; zaruretler haramları mubah kılar; haramlarda taabbudilik (haram kılınan fiillerin sırf Allah emrettiği için terkedilmesi) esastır; helal dairesi harama ihtiyaç bırakmayacak kadar geniştir. Helâl ve haramlarla ilgili kâide ve prensipler istikra yöntemiyle, yani bu konudaki hükümlere bütüncül bir bakışla çıkarılmıştır. Dolayısıyla söz konusu kâide ve prensipleri burada sayılanlarla sınırlı görmek doğru değildir. Bu konuda yapılacak daha geniş ve derin çalışmalarla elbette yeni bir kısım kâidelerin çıkarılması mümkün olacaktır. Fakat görebildiğimiz kadarıyla kavaid kitaplarının konuyla ilgili ele aldıkları başlıca kâideler bunlardan ibarettir.

Anahtar sözcükler- Helâl, Haram, Zaruret, Zarar ve Hile

\section{$\S \S \S$}

Makalenin gelişi: 08.05.2018; Yayına kabul tarihi: 12.06.2018

* Marmara Üniversitesi SBE. Temel İslâm Bilimleri Anabilim Dalı (İslâm Hukuku) doktora mezunu (2013); herhangi bir kurumda çalışmıyor, e-posta: yukselcayiroglu@gmail.com (ORCID: 0000-0002-3044-9525) 


\section{Giriş}

Helâl, mükellefin yapıp yapmamada serbest bırakıldığı ve işlenmesine herhangi bir ceza ve günah terettüp etmeyen fiilleri; ${ }^{1}$ haram ise yapılması kesin ve bağlayıcı bir tarzda yasaklanan ve yapılması durumunda da uhrevî cezayı gerektiren fiilleri ifade eder. ${ }^{2}$ Aralarında küçük farklar olsa da helâl yerine mubah ve caiz kelimelerini; haram yerine de günah, mahzurlu, memnû' ve masiyet kelimelerini kullanmak mümkündür. Haram bir fiilden bahsedebilmek için mutlaka konuyla ilgili kat'î bir nass bulunması gerekirken, helâl için yasaklayıcı bir delilin bulunmaması yeterlidir.

Yüce Allah, inançla ilgili meselelerden ibadetlere, ticarî hayattan yiyecek ve içeceklere, aile hayatından sosyal münasebetlere kadar hayatın her alanıyla ilgili bir kısım sınırlar çizmiş ve yasaklar koymuştur. Bütün bu yasakların şer'î ahkâm içerisinde mühim bir yeri vardır. Dinin ve Müslüman kimliğinin korunması da bu yasaklara riayet etmeye bağlıdır. Bu sebepledir ki Kur'ân'da yer alan farklı ayetlerde haramları ifade etmek üzere ححُدودُ اللِّ "Allah'ın sınırları" kavramı kullanılmış, ${ }^{3} \mathrm{~Hz}$. Peygamber (s.a.s) de haramların Allah'ın korusu olduğunu ifade etmiştir. ${ }^{4}$ Suyûtî de Yüce Allah'ın haramların terk edilmesine verdiği önemin, farzların işlenmesine gösterdiği önemden daha büyük olduğunu ifade etmiştir. ${ }^{5}$ "Def-i mefâsid celb-i menâfiden evlâdır." küllî kâidesi de bu manayı desteklemektedir.

Helâl ve haramlarla ilgili vazedilen hükümlerin asıl amacı, Allah'a karŞı gösterilmesi gereken teslimiyet ve bağlıı̆ın ortaya konulmasıdır. Kulluk bilincinin gelişmesi ve dünya imtihanının kazanılması adına bu sınırlara riayet etmek hayatî bir öneme sahiptir. Zira bu sınırları bizzat Yüce Allah belirlemiş, kesin ve bağlayıcı bir üslupla mükelleflerden bu sınırlara uymalarını istemiş ve buna riayet etmeyenlerin uhrevî cezaya maruz kalacaklarını bildirmiştir. ${ }^{6} \mathrm{Bu}$

Ali b. Muhammed es-Seyyid eş-Şerif el-Cürcânî, Ta'rifât, (Beyrut: Dâru'l-kütübi'l-ilmiyye, 1983), 92; Muhammed Ebû Zehre, Usûlü'l-fıkh, (Kahire: Dâru'l-fikri'l-Arabî), 46.

2 Râgıb el-İsfehânî, el-Müfredât fî garîbi'l-Kur'ân, (Dımeşk: Dâru'l-kalem, 1412), 229-230; Ebu Zehre, Usûlüll-fıkh, 42.

3 el-Bakara 2/187, 229, 230; en-Nisâ 4/13; el-Mücâdele 58/4; et-Talâk 64/1.

4 Buharî, "Îmân", 39; Müslim, "Müsâkât", 107.

5 Celâlüddin b. Ebî Bekr es-Suyûtî, el-Eşbâh ve'n-nezâir, (Beyrut: Dâru'l-kütübi'l-ilmiyye, 1403), 1: 87.

6 Haram hükmünün sabit olması için ayet veya hadislerdeki yasaklama ifadesinin kesin ve bağlayıcı bir üslûpla gelmesi gerektiği konusunda mezhepler arasında ittifak bulunsa da, haram hükmüne kaynaklık eden delilin kat'î olmasının gerekip gerekmediği noktasında ihtilâf bulunmaktadır. Hanefilere göre haram kılıcı delilin kat'i olması zorunlu iken, diğer mezhepler kat'î delilin yanı sıra zannî delil ile de haramlık hükmünün sabit olacağını ifade etmişlerdir. Usuldeki böyle bir ihtilâf bir kısım fiillerin hükmüne de yansımış ve bir kısım yasaklarla ilgili 
durumda mükelleflere düşen vazife de dinin belirlemiş olduğu bu "kırmızı çizgileri" aşmamaktır.

Öte yandan haramlara riayet etmek, toplum hayatının dirlik ve düzeninin korunması adına çok önemlidir. Zira şer'î hükümlerin gerçekleştirmeyi hedeflediği zarurî, hâcî ve tahsinî maslahatların elde edilmesi büyük ölçüde yasakların ihlâl edilmemesine bağlıdır. Hususiyle haramlardan uzak durmaksızın dinin, nefsin, neslin, aklın ve malın korunmasından ibaret olan zarurî maslahatların korunabilmesi mümkün değildir. Esasında İslâm'ın getirmiş olduğu en önemli yasakların da bunlarla ilgili olduğu görülecektir. Bu yasakların korunamadığı bir toplumda telafisi mümkün olmayan büyük zararlar ortaya çıkacak, insanların can ve mal güvenliği kalmayacaktır.

İslâm'da yer alan helâl ve haramların günümüzün evrensel değerleri ve ahlâkî ilkeleriyle sıkı bir münasebetinin olduğu da gözden kaçırılmamalıdır. Eğer günümüzde genel anlamda bir ahlâkî kriz yaşanıyor ve toplum ciddî bir dejenerasyona maruz kalıyorsa, hiç şüphesiz bunun en başta gelen sebeplerinden birisi helâl-haram hassasiyetinin kaybolmasıdır. Dolayısıyla Kur'ân ve Sünnet'te yer alan yasakların önemli hedeflerinden birisi de ahlâklı fertlerden oluşan temiz bir toplum inşasıdır.

Âlimler, helâl ve haramların temel mantığını kavrama ve konuyla ilgili hükümlerin doğru bir şekilde tespit edilebilmesi adına bir kısım temel ilkeler ortaya koymuşlardır. Hiç şüphesiz bunların bilinmesi bir taraftan İslâm'ın daha iyi anlaşılmasına katkıda bulunacak, diğer yandan da konuyla ilgili yapılacak araştırma ve çalışmalara yön verecektir.

İslâm'da yer alan helâl ve haramlarla ilgili kitap yazan âlimler, ${ }^{7}$ eserlerinin başında konuyla ilgili bir kısım ilkeler üzerinde durmuş olsalar da bu kısa izahlar konunun anlaşılması adına yeterli değildir. Muttali olabildiğimiz kadarıyla bu alanda yapılmış müstakil bir çalışma yoktur. Dolayısıyla bu araştırmada, daha önce tarafımızdan hazırlanan doktora tezinin ilk bölümünde yer alan konuyla ilgili bir kısım ilkeler genişletilmiş, bunlara yenileri eklenmiş ve böylece konu müstakil bir makaleye dönüştürülmüştür.

fakihler tarafından mekruh veya haram olmak üzere farklı hükümler verilmiştir. (Ebu Zehre, Usulüll-fıkh, 42) Hatta delillerin tearuzu, tahsis ve takyidi gibi bir kısım usulî meselelerden ötürü, bazı fakihlerce mekruh veya haram görülen bir kısım fiiller, başkalarınca mubah görülebilmiştir. Fakat teferruata ait bu gibi meseleleri istisna edecek olursak, haram fillerin büyük kısmı hakkında fakihler arasında ittifak bulunmaktadır.

7 Bkz. Yusuf el-Karadâvi, el-Halâl ve'l-harâm fi'l-İslâm, (Beyrut: el-Mektebetü'l-i̇slâmî, 1994, 5. baskı); Hayrettin Karaman, Günlük Hayatımızda Helâller ve Haramlar, (İstanbul: İz Yay., 2000). 
Bizim, bu araştırmadaki maksadımız, helâl ve haramlarla ilgili fıkıh ve kavâid kitaplarında dağınık halde zikredilen kâide ve ilkeleri bir araya toplayarak, bunların izahını yapmak ve böylece dinî ahkâmın içerisinde önemli bir yere sahip olan haramların ortak özelliklerini ve temel mantığını göstermektir. Ayrıca söz konusu kâide ve ilkelerin bilinmesi, bir taraftan mükelleflerin helâl ve haram hükümleri doğru bir şekilde hayatlarına tatbik etmelerine yardımcı olacağı gibi, diğer yandan da fetva ve içtihat faaliyetlerinin usulüne uygun yürütülebilmesine yardımcı olacaktır. Bu alandaki kâide ve ilkelerin bilinmesinin, kolaylığın asıl olması, ihtiyat ilkesinin gözetilmesi ve kulların maslahatlarının sağlanması gibi İslâm fıkhının karakteristik özelliklerinin daha iyi anlaşımasına katkı sunacağı da bir gerçektir.

Bütün bunların yanında bu çalışma, helâl ve haramlarla ilgili farklı yerlerde özet olarak değinilen veya kısaca işaret edilen kâide ve ilkelerin anlam ve kapsamını geniş olarak açıklığa kavuşturmayı ve bunların helâl ve haram hükümlerinin belirlenmesinde ne gibi bir fonksiyon üstlendiğini izah etmeyi amaçlamıştır. Zira özellikle günümüzde modern hayatla birlikte çözülmesi gereken pek çok fıkhî mesele karşımıza çıkmıştır. Helâl ve haramlarla ilgili burada izahı yapılan kâide ve ilkeler, tek başlarına bir hüküm kaynağı olma özelliğine sahip olmasalar da; bunlar, kazandırdıkları bakış açısıyla helâl veya haramlık hükümlerinin doğru bir şekilde tespit edilebilmesinde önemli rol oynayacaktır.

Son olarak başlıkta yer alan "kâide" ve "ilke" kelimelerinin kısaca izahlarının yapılması ve alt başlıklarda yer alan umumî hüküm ve kaziyyeleri ifade etmek üzere niçin bu kelimelerin seçildiğinin açıklanması da faydalı olacaktır. Kâideyle ilgili birbirine yakın pek çok tarif yapılmış olsa da kısaca o, birçok cüzî hükmü altında toplayan küllî bir asıl ve farklı fıkhî meseleleri kuşatan külî bir kazıyyedir. Genellikle kâide ile birlikte kullanılan ve aralarında cüz-kül münasebeti bulunan dâbıt ise fıkhın sadece bir bölümüne ait hükümleri kapsayan küllî bir kazıyyedir. 8

Aslında bu çalışmada ele alınan asılların kâide yerine dâbıt olarak isimlendirilmesi kavramların teknik kullanımı açısından daha yerinde olurdu. Zira burada geçen kâideler, fıkhın bütün konularıyla değil, sadece helâl ve haram hükümleriyle ilgilidir. Ne var ki kâide ve dâbıt arasında kapsam ve kuşatıcılık açısından fark bulunsa da, eda ettikleri fonksiyon ve temel yapıları

8 Kâide ve dâbıt kelimelerinin sözlük ve terim anlamları için bkz. Yakub b. Abdilvehhâb elBâhuseyn, el-Mufassal fi'l-kavâidi'-fıkhiyye, (Riyâd: Dâru't-tedmuriyye, 2011), 23-36, 56-61; Necmettin Kızılkaya, "Hanefi Mezhebinde Kavâid İlmi ve Gelişimi”, (Doktora Tezi, Selçuk Üniversitesi, 2011), 15-41. 
itibarıyla her ikisi de aynıdır. Farklı bir ifadeyle aslında her dâbıt, aynı zamanda bir kâidedir. Nitekim âlimlerin bir kısmı da bu iki kavramı birbirinden ayırmamış ve her ikisi için de aynı tarifi vermişlerdir. ${ }^{9}$ İşte bu sebepledir ki başlıkta, daha az kullanılan ve daha az bilinen dâbıt kelimesi yerine, daha yaygın bir kullanıma sahip olan kâide kelimesi tercih edilmiştir.

Öte yandan burada yer alan esasların veya külî hükümlerin tamamının bir fıkıh kâidesi olmadığı da bir gerçektir. Meselâ, "Helâl ve haram kılma yetkisi Allah'a aittir.", "Haramlarda taabbudîlik esastır." veya "Helâl dairesi harama intiyaç bırakmayacak kadar geniştir." şeklinde dile getirilen küllî kaziyyeler, teknik anlamıyla kavaid-i külliyeden değildir. Bu açıdan burada yer alan bütün esasları intiva etmesi adına, başlıkta kâidenin yanında ilke kelimesi de kullanılmıştır. Arapça'da "mebde-mebâdi", İngilizce'de ise "principle" kelimeleriyle ifade edilen ilke ise, genel itibarıyla farklı bilgi, hüküm ve kazıyyelere kaynaklık eden temel, esas ve umde anlamında kullanılmaktadır. ${ }^{10}$ Dolayısıyla yukarıda bahsedilen esaslar, her ne kadar birer fıkıh kâidesi olmasalar da, pek çok fıkhî ahkâma kaynaklık etmeleri ve onların ortak özelliklerini yansıtmaları açısından birer ilke olduklarında şüphe yoktur.

\section{Helâl ve Haram Kılma Yetkisi Yalnız Allah'a Aittir}

Kur'ân-ı Kerim'de birçok ayette haram kılma yetkisinin yalnız Allah'a ait olduğu ısrarla vurgulanmış ve bu konuda haddi aşanlar levm edilmiştir. ${ }^{11}$ Çünkü helâl ve haram kılma yetkisi, doğrudan iman ve tevhitle alâkalı bir meseledir. Nitekim "(Yahudiler) Allah'ı bırakıp hahamlarını, (Hıristiyanlar) da rahiplerini ve Meryem oğlu Mesîh'i rabler edindiler." 12 ayeti nazil olduğunda, Müslüman olmadan önce Hıristiyanlık dinini benimsemiş olan Adiy b. Hâtim, Hz. Peygamber'e gelerek, "Yâ Resûlallah! Onlar bunlara ibadet etmediler." demiş, Allah Resûlü de ona şu cevabı vermiştir: "Evet, dediğin doğrudur. Ancak bunlar onlara helâli haram kılmış, haramı da helâl kılmışlar, onlar da bunları uygulamışlardır. İşte onların bunlara ibadeti bundan ibarettir."13

Haram ve helâl kılma yetkisinin sadece Allah'a ait olduğunu beyan eden başlıca ayetler şunlardır: "Beyinsizlikleri yüzünden, körü körüne çocuklarını öldürenler ve Allah'ın kendilerine verdiği nimetleri Allah'a iftira ederek

9 Bâhuseyn, el-Mufassal, 56-57.

10 İlke kelimesinin, mantıkta, bilimde ve ahlâkta ifade ettiği anlamlar için bkz. Ahmed Cevizci, Felsefe Sözlügü, (İstanbul, Paradigma yayınları, 1999), 459-460.

11 el-Mâide 5/103; el-En'âm 6/143-144.

12 et-Tevbe $7 / 31$.

13 Tirmizî, "Tefsîru's-sûre”, 9,10. 
haram sayanlar mahvolmuşlardır; onlar sapıtmışlardır, zaten doğru yolda da değillerdi." "14; "Dillerinizin yalan yere nitelendirmesinden ötürü, 'Şu helâldir; şu haramdır.' demeyin. Sonra Allah'a karşı yalan uydurmuş olursunuz. Allah'a karşı yalan uyduranlar ise iflah olmazlar."15; "De ki: Allah'ın kulları için yaratıp ortaya çıkardığı ziyneti, temiz ve hoş rızıkları haram kılmak kimin haddine?"16; “De ki: Allah'ın size indirdiği rızkın bir kısmını haram, bir kısmını helâl kıldığınızı görmüyor musunuz? De ki: Size Allah mı izin verdi, yoksa Allah'a karşı yalan mı uyduruyorsunuz?"17; "Ey İnananlar! Allah'ın size helâl ettiği temiz şeyleri haram kılmayın, hududu da aşmayın. Doğrusu Allah aşırı gidenleri sevmez."18

Görüldüğü gibi Kur'ân, birçok ayet-i kerimede haram ve helâl kılma yetkisinin sadece Allah'a ait olduğunu dile getirmekle makamı ve derecesi her ne olursa olsun hiç kimsenin bu konuda bir yetkisinin olmadığını ifade etmiştir. Bu hükme peygamberler ve onların yerini tutan âlim ve yöneticiler de dâhildir. Zira peygamberler helâl ve haram kılma yetkisini Allah'tan alırlar. Helâl ve haram kılma yetkisi hakikî manada Allah'a ait olduğu için peygamberlere verilen bu yetki mecazîdir. ${ }^{19} \mathrm{~Hz}$. Peygamber'in bu konudaki yetkisinin de Allah'ın hüküm ve iradesini belirleme ve açıklamaktan ibaret olduğu ifade edilmiştir. ${ }^{20}$

Konuyla ilgili ayetlerin tehdidi karşısında selef ulemasından birçokları hakkında kesin ve açık nass bulunmayan meselelerle ilgili fetva verirken haram lafzını kullanmaktan kaçınmışlardır. Nitekim İmam Şafiî, el-Ümm isimli kitabında, Ebû Yusuf'un şu sözlerini nakletmiştir: "Ehl-i ilim olan şeyhlerimizden öyle kimselere yetiştim ki onlar, fetva verirken, 'Bu helâldir; bu haramdır.' demeyi kerih görüyorlardı. Onlar, ancak Kur'ân-ı Kerim'de hakkında tevil ve tefsire kapalı, açık nass bulunan meselelerde bunu söylüyorlardı."21

İbrahim en-Nehâî de konuyla ilgili âlimlerin tutumunu şu ifadeleriyle anlatmıştır: "Onlar herhangi bir konuda fetva verirken veya bir şeyin yasaklandığını anlatırken, 'Bu, mekruhtur.' veya 'Bundan bir beis yoktur.' derlerdi. Zira

\footnotetext{
14 el-En'âm 6/140.

15 en-Nahl 16/116.

16 el-Â'râf $7 / 32$.

17 Yunus 10/59.

18 el-Mâide 5/87.

19 Mehmet Erdoğan v.dğr., İslâm İlmihali, (İstanbul: Marmara İlahiyat Vakfı Yay., 2006), 653.

20 Abdullah Kahraman, "İslâm'da Helâl ve Haramın Yeri ve Fıkıh Usulü Açısından Temellendirilmesi", İslâm Hukuku Araştırmaları Dergisi 20, (2012): 61.

21 Muhammed b. İdris eş-Şafî,, el-Ümm, (Beyrut: Dâru'l-ma'rife, 1393), 7: 351.
} 
'Bu helâldir; şu haramdır.' denilmesi ne kadar da büyük bir iştir." 22 Ahmed b. Hanbel'e bir mesele hakkında soru sorulduğunda onun da, "Bunu kerih görüyorum." veya "Bu, hoşuma gitmez." ya da "Bunu sevmiyorum." gibi ifadelerle cevap verdiği nakledilmiştir. ${ }^{23}$

\section{Eşyada Asıl Olan İbahadır}

Bir nesnenin veya bir fiili yapmanın mubah olduğu ibaha-i şer'iyye ve ibaha-i asliyye olmak üzere iki şekilde anlaşılır. İbaha-i şer'iyye, Şâri' Teâlâ'nın hitabı ile sabit olur ve söz konusu fiili yapıp yapmama hakkında mükelleflerin muhayyer bırakıldığını ifade eder. İbaha-i asliyye ise hakkında bir yasaklama söz konusu olmayan şeylerin mubah olduğunu ifade eder ve ibaha-i asliye ile mubah olan fiilleri yapan mükellefler bu konuda muahaze edilmezler. ${ }^{24}$ Zira Nebiyy-i Ekrem'e yağ, peynir ve yaban eşeğinin hükmü sorulduğunda şöyle cevap vermiştir: "Helâl, Allah'ın kitabında helâl kıldığı, haram da Allah'ın kitabında haram kıldığıdır. Sükût geçtiği şeyler ise bağışladıklarındandır."25

Konuyla ilgili diğer bir rivayet de şu şekildedir: "Allah bazı şeyleri farz kılmıştır, bunları zayi etmeyin; bazı sınırlar koymuştur, bunları da aşmayın; bazı şeyleri haram kılmıştır, bunları çiğnemeyin; unutmaktan değil, size olan rahmetinden dolayı bazı şeyler hakkında da bir şey buyurmamıştır, bunları da soruşturmayın."26

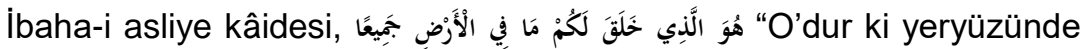
bulunan her şeyi sizin için yarattı." ${ }^{77}$ ayetinden istidlâl edilmiştir. Çünkü ayette geçen í ismi umum ifade etmekte, ayetin sonundaki جمَيًَ lafzıyla da bu mana kuvvetlenmektedir. Bunun yanında bir de كَ كُم kelimesindeki "lam" harf-i ceri nimetlerden istifade açısından bir ihtisas ifade etmektedir. Böylece kulların

22 İmam Şafiî, el-Ümm, 7: 351.

23 Karadâvi, el-Halâl ve'l-harâm, 28.

24 Mehmet Seyyid, Medhal, Latinize: Selçuk Camcı, (İzmir: Yeni Akademi Yay., 2010), 76.

25 Tirmizî, "Et'ime", 60; İbn Mâce, "Et'ime", 60; Ebû Abdullah Muhammed b. Abdullah el-Hâkim en-Nisâburî, el-Müstedrek ala's-Sahihayn, thk. Mustafa Abdülkadir Ata, (Beyrut: Dâru'lkütübi'l-ilmiyye, 1990), 4: 129.

26 Hâkim, el-Müstedrek, 4: 129; Ebû'l-Hüseyn Ali b. Ömer ed-Darakutnî, Sünen, thk. Abdullah Hâşim el-Yemânî, (Beyrut: Dâru'l-ma'rife, 1966), 4: 183; Ebû Bekr Ahmed b. el-Hüseyin b. Ali el-Beyhakî, es-Sünenü'l-kübrâ, (Haydarabad: Dâiretü'l-maârifi'l-Osmaniyye, 1344), 10: 12.

27 el-Bakara 2/29. 
yeryüzünde yaratılan her şeyden istifade etmeye şer'an izinli bulundukları anlaşılmaktadır. ${ }^{28}$

Diğer taraftan bu ayet minnet ve insan makamında gelmiştir. Haram ve necis maddelerden faydalanma helâl olmadığı için bir minnet olamayacağına göre demek ki aksine bir delil olmadığı sürece yeryüzündeki bütün nimetler mubahtır. ${ }^{29}$ Menar sahibinin ifadesiyle buradaki mubahlıktan kasıt ise yeme, içme, giyme, tedavi olma, binme ve ziynet gibi faydalanma çeşitleridir. ${ }^{30}$

Kur'ân'da bu ayeti destekleyen daha başka ayetler de vardır. Örnek olarak şunları verebiliriz: "Göklerde ve yerde olanların hepsini sizin buyruğunuz altına vermiştir."31; "Görmüyor musunuz ki Allah göklerde ve yerde olan şeyleri sizin hizmetinize vermiş ve görünen görünmeyen bunca nimete sizi garketmiştir?"32

Hakkında nass bulunmayan meselelerin ibaha-i asliye kâidesine göre helâl oldukları ifade edilse de yukarıdaki nasslardan yola çıkarak artık bunların mubahlığının ibaha-i asliye değil ibaha-i şer'iye nevinden olduğunu söylemek de mümkündür. Çünkü Yüce Allah, minnet makamında yeryüzündeki her şeyi kulları için yarattığını ifade buyurduğundan, haramların dışındaki nesnelerin helâl/mubah oldukları bizzat ayetle sabit olmaktadır. ${ }^{33}$

İbaha-i asliye prensibinin sadece eşya ve âyâna münhasır olduğu zannedilmemelidir. Bilâkis ibadetlerle ilgili olmayan muamelât ve âdât nevinden fiil ve tasarruflar da bu kuralın kapsamı dâhilindedir. Çünkü Yüce Allah, "Muhakkak Allah size haram kıldığı şeyleri açıkça bildirmiştir." 34 sözüyle kullarına haram kıldığı bütün şeyleri beyan ettiğini haber vermiştir. Buna göre âyânda olduğu gibi, hakkında haramlık sabit olmayan fiil ve tasarruflarda da esas olan mubahlıktır. ${ }^{35}$

28 Cemâlüddin Abdurrahman el-İsnevî, Nihâyetu's-sûl şerhu Minhâci'l-vusûl, (Beyrut: Dâru'lkütübi'l-ilmiyye, 1999), 2: 235.

29 Nezih Hammâd, el-Mevâddü'l-muharreme ve'n-necisât fi'l-gızâi ve'd-devâi beyne'n-nazariyyeti ve't-tatbîk, (Dimeşk: Dâru'l-kalem, 2. Baskı, 2011), 17; Kâmil Musâ, Ahkâmu'l-et'ime fi'lİslâm, (Beyrut: Müessesetü'r-risâle, 1986), 32.

30 Muhammed Reşid er-Rıza, Tefsiru'l-menâr, (Kahire: el-Hey'etü'l-Mısriyyeti'l-âmmeti li'l-kütüb, 1990) 1: 206.

31 el-Câsiye 45/13.

32 Lokmân 31/20.

33 Mehmet Seyyid, Medhal, 76.

34 el-En'âm 6/119.

35 Zeynüddin Zeyn b. İbrâhim b. Muhammed b. Nüceym, el-Eşbâh ve'n-nezâir, thk. Abdülkerim el-Fudaylî, (Beyrut: el-Mektebetü'l-asriyye, 2003), 87-88; Karadâvi, el-Halâl ve'l-harâm, 24; Musâ, Ahkâmu'l-et'ime, 33. 
İbadetlere gelince onlar, vahiyle sabit olduklarından onlar hakkında esas olan tevkîfî olmalarıdır. Yani ibadetlerin vakit, mekân ve şeklini tayin etmek ancak vahiyle mümkün olabilir. Bu konuda kulların hiçbir dahli söz konusu değildir. Muamelat alanında da nikâh, ibaha-i asliyeden istisna tutulmuş ve "Nikâhta asıl olan haramlıktır." kâidesi kabul edilmiştir. ${ }^{36}$ Bazıları çerçeveyi biraz daha genişleterek helâl olması bir kısım şartlara bağlanmış olan diğer fiillerde de asıl olanın haramlık olduğunu ifade etmişlerdir. Mesela bir hayvanın helâl olması için boğazlamanın bazı şartları bulunduğundan dolayı, "Boğazlanmış hayvanların yenilmesinde asıl olan haramlıktır." kâidesini getirmişlerdir. ${ }^{37}$

\section{Menfaatlerde Helâllik Zararlarda ise Haramlık Asıldır}

Fakihlerin, helâl ve haramlarla ilgili pek çok nasstan süzerek çıkarmış oldukları kâidelerden bir diğeri de şudur: "Faydalı şeylerde asıl olan mubahlık; zararlı şeylerde asıl olan ise haramlıktır." ${ }^{38}$ Bu kâide aynı zamanda, mütekellimîn metoduna göre yazılan bazı usul kitaplarında, meşruiyet delillerinden birisi olarak zikredilmiştir. Bu kitaplarda öncelikle Kitap, Sünnet, icma ve kıyastan oluşan aslî delillere yer verilmiş, arkasından "Hakkında İhtilâf Edilen Deliller” başlığı altında ferî deliller açıklanmıştır. İşte istishâbü'l-hâl, istihsan, kavlü's-sahabî, el-mesâlihu'l-mürsele, el-ehzu bi ekalli mâ kîl ve istikra gibi delillerin yanında, "Faydalı şeylerde ası olan mubahlık; zararlı şeylerde ası olan ise haramlıktır." ilkesi de bu delillerden birisi olarak zikredilmiştir. ${ }^{39}$

Bu kâide/delil, helâl ve haram kılınan nesne ve fiillerin anlaşılmasında önemli bir asıl olduğu gibi, aynı zamanda hakkında açık bir nass bulunmayan meselelerde hüküm verirken de göz önünde bulundurulması gereken önemli bir ilkedir. Biraz daha açacak olursak Yüce Allah, giyim-kuşam, eğlence, yeme-içme, sosyal münasebetler, aile hayatı, akit ve tasarruflar gibi hayatın değişik yönleriyle ilgili bir kısım sınırlar koymuş, bazı fiilleri yasaklarken, bazılarını serbest bırakmıştır. İşte istikra metoduyla İslâm'da yer alan helâl ve haramlara bakıldığında, bunların kullar adına gerek maddî ve manevî, gerek dünyevî ve uhrevî, gerekse ferdî ve ictimaî bir kısım maslahatları gerçekleş-

36 İbn Nüceym, el-Eşbâh ve'n-nezâir, 87-88; Karadâvi, el-Halâl ve'l-harâm, 24; Musâ, Ahkâmu'let'ime, 33.

37 Yahya Musa, "el-Kavâidu'l-fıkhiyye fi'ctimâil'halâli ve'l-haram ve ta'tbîkatuhâ'l-muâsıra", (Doktora Tezi, el-Câmiatu'l-Ürdüniyye, 2004), 177.

38 Ahmed b. İdris b. Abdirrahim el-Karafî, Envâru'l-burûk fî envâi'l-furûk, thk. Halil el-Mansûr, (Beyrut: Dâru'l-kütübi'l-ilmiyye, 1998), 1: 20; Fahruddin Muhammed b. Ömer er-Râzî, elMahsûl, (Müessesetü'r-risâle, 1997), 6: 97; Sübkî, el-libhâc, 3: 165.

39 İsnevî, el-libhâc, 3: 165; Râzî, el-Mahsûl, 6: 97; Bedrüddin Muhammed b. Abdullah ezZerkeşî, el-Bahru'l-muhît fî usûli'l-fıkh, (Dâru'l-kütüb, 1994), 8: 8. 
tirmeye ve mefsedetleri uzaklaştırmaya yönelik olduğu görülecektir. Yani Allah, kullarına rahmet ve şefkatinin bir gereği olarak, onlar için zararlı olan fiil ve tasarrufları haram kılarken, faydalı olanları helâl kılmıştır. ${ }^{40}$

Dolayısıyla hakkında nass bulunmayan bir kısım güncel problemlerin çözümünde de fayda-zarar, maslahat-mefsedet kriterinin göz önünde bulundurulması teşri felsefesine uygun hareket tarzı olacaktır. Farklı bir ifadeyle şeriatin sükût ettiği meseleler hükme bağlanırken onların kullar açısından intiva ettiği maslahat ve mefsedetlere bakılacak; maslahat yönü ağır olanlar hakkında mubah, mefsedet yönü ağır olanlar hakkında ise haramlık hükmü sabit olacaktır. Mesela bu kâideye göre, faydalı olmasından hareketle sarhoş edici özelliği bulunmayan meyve suları hakkında mubah hükmü verilirken, zararlı olmasından hareketle sigara hakkında haram veya tahrimen mekruh hükmü verilmiştir. ${ }^{41}$

Nasslarda yer alan helâl ve haramların fayda-zarar kriterine göre değerlendirilmesinde ittifak edilse de yeni hukukî olayların bu ilkeye göre hükme bağlanması hakkında farklı görüşler öne sürülmüştür. Ayrıca bu mesele, hüsün-kubuh konusuyla yakından alâkalı olduğundan, hüsün-kubuhla ilgili yaklaşımlar burada da etkisini göstermiştir. Mutezile, aklın tek başına iyi ve kötüyü idrak edebileceğini ve bu idrake göre fiillerin mubah veya haram kabul edileceğini savunmak suretiyle, aklın şer'î hükümlerin kaynağı olabileceğini ileri sürmüştür. ${ }^{42}$ Ehl-i Sünnet kelâmcıları ise Mutezilenin bu görüşüne itiraz etmiş, nassın bulunmadığı yerde şer'î bir hükümden de bahsedilemeyeceğini savunmuşlardır. ${ }^{43}$ Haramlık hükmü için şer'î bir delilin bulunması gerektiğine işaret eden söz konusu yaklaşımların yanı sıra haram kılma yetkisinin yalnız Allah'a ait olduğunu bildiren âyet ve hadisler de söz konusu kâideyle ilgili farklı görüşlerin öne sürülmesine sebep olmuştur. ${ }^{44}$

Bu itibarla söz konusu kâideyi kabul eden fakihler, faydalı olan fiilleri helâl, zararlı olan fiilleri ise haram kabul etmenin aklî bir hüküm olmadığını, bilâkis bunun şer'î delillere dayandığını belirtme lüzumunu duymuş ve tek tek

40 Muhammed Sıddıkî b. Ahmed el-Gazzî, Mevsûatü'l-kavâidi'l-fıkhiyye, (Beyrut: Müessesetü'rrisâle, 2003), 2: 24.

41 Gazzî, Mevsûatü'l-kavâidi'l-fıkhiyye, 2: 24.

42 Bu konudaki farklı yaklaşımlar için bkz. Seyyit Mehmet Uğur, "Fıkıh Usulünde Haram Kavramı”, (Yüksek Lisans Tezi, Marmara Üniversitesi, 2009), 93-95.

43 Konuyla ilgili olan hüsün ve kubuh'un aklî veya şer'î olduğu, fiillerin mahiyetleri itibarıyla iyilik ve kötülük içerip içermediği, aklın tek başına fiillerin iyilik veya kötülüğünü idrak edip edemeyeceği hakkındaki tartışmalara burada yer vermiyoruz.

44 Bkz. İlyas Çelebi, "Hüsün-Kubuh", Türkiye Diyanet Vakfı İslâm Ansiklopedisi, c. 19 (İstanbul: TDY Yay., 1999), 59-63. 


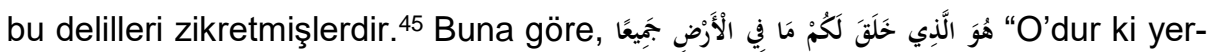

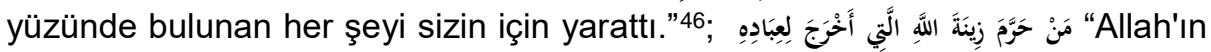

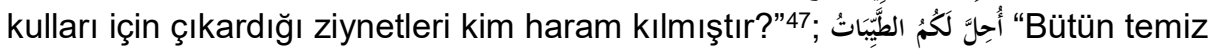
ve iyi rızıklar size helâl kılınmıştır." 48 ayetleri faydalı şeylerin helâl olduğuna delil getirilmiştir. ${ }^{49}$

İlk âyette geçen لكُمْ lafzındaki "lam” harf-i cerinin nef' için kullanıldığı ve dolayısıyla kendisinden istifade edilen faydalı şeylerin şer'an mubah olduğuna delâlet ettiği; ikinci ayetteki "zinet" lafzının güzel, hoş ve faydalı şeyler

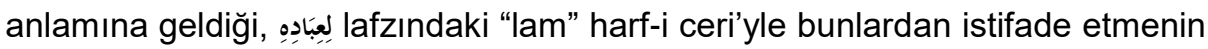
insanlara mahsus kılındığı ve istifham-ı inkârî ile bu istifadenin haram kılınmasının nefyedildiği; aynı şekilde üçüncü ayette yer alan "tayyibat" kelimesiyle tab'an hoş ve güzel olan şeylerin kastedildiği, كُّ lafzıyla bunların insanların istifade etmesi için yaratıldığı ve أُجِلَّ lafzıyla da onların kullanılmasının helâl kılındığı ifade edilmiş ve böylece söz konusu ayetlerin faydalı olan bütün şeylerin helâlliğine delâlet ettiği ifade edilmiştir. ${ }^{50}$

Zararlı olan şeylerin haram olduğu şeklindeki ilkenin istidlâl edildiği temel delil ise Hz. Peygamber'in şu sözüdür: لَا ضَرَرَ لََلَا ضِرَارَ 'Zarar vermek ve zarara zararla mukabele etmek yoktur." ${ }^{51} \mathrm{Bu}$ hadis, zararın her türlüsünü mutlak olarak nefyetmektedir. Çünkü burada hem cinsini nefyeden "lâ" edatı kullanılmış, hem de "zarar" kelimesi nekre olarak gelmiştir. Dolayısıyla bu, âmm bir lafız olup, amm lafızlar ise tahsis söz konusu olmadığı sürece lafzın delâlet ettiği bütün manaları muhtevidir. Hadisteki zararı nefyeden ifade, bunun imkânını veya vukuunu değil, cevazını nefyetmektedir. Cevaz nefyedildiğinde ise haramlık hükmü sabit olacaktır. ${ }^{52}$

Fakihler, söz konusu hadis gereğince bir şeyi kullanmanın haram olmasının şu gibi yollardan biriyle gerçekleşeceğini kaydetmişlerdir: Uyuşturucu gibi insana sarhoşluk vermesi ve aklı gidermesi; toprak veya panzehir gibi bedene zararlı olması; tükürük ve balgam gibi insana tiksinti vermesi. Söz

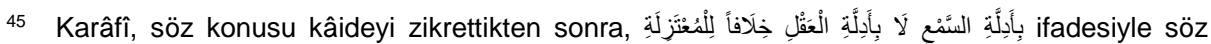
konusu kâidenin aklî delillere değil, sem'î delillere dayandığını zikretmiş ve Mu'tezile'nin bunun hilâfına olduklarını belirtmiştir. (Karâfî, Şerhu tenkîhi'l-fusûl, (Şeriketü't-tıbâati'lfenniyeti'l-müttehide, 1973), 451)

46 el-Bakara 2/29.

47 el-Â'râf $7 / 32$.

48 el-Mâide 5/4.

49 Râzî, el-Mahsûl, 6: 97-98.

50 Karafî, el-Furûk, 1: 220; İsnevî, Nihâyetü's-sûl, 360.

51 İbn Mâce, "Ahkâm", 17.

52 İsnevî, Nihâyetü's-sûl, 360. 
konusu maddeler şer'an temiz kabul edilseler de zararlı oldukları için haram hükmünü almışlardır. ${ }^{53}$

Yukarıdaki hadisin yanı sıra, Kur'ân'da yer alan, "Kendinizi öldürmeyin."54; "Kendi ellerinizle kendinizi tehlikeye atmayın!"55 ayetlerinin de muhtevi olduğu pek çok mananın yanında zararlı şeyleri nehyettiğine delâlet ettiğini söylemek mümkündür. Zira bir insanın akıl, ruh veya beden sağlığına zarar verecek yiyecekleri tüketmesi veya fiilleri işlemesi de hem kendisini tehlikeye atması hem de nefsinin helâkine sebebiyet verebilecek bir yola girmesi demektir.

Hz. Peygamber'in teşri yetkisini bildiren, "O, onlara tayyib olan şeyleri helâl, habîs olan şeyleri de haram kılar." ${ }^{6}$ ayeti de hususî bir delil bulunmadığı sürece helâl ve haramların tayininde müracaat edilmesi gereken önemli bir asıldır. Söz konusu ayet genel itibarıyla yiyecek ve içeceklerin hükmünü tespit etme sadedinde ele alınsa da diğer haramların belirlenmesinde de habis ve tayyib olma kriterlerinin yönlendirici olacağında şüphe yoktur. Tayyib sözlükte, temiz, iyi, hoş, güzel, lezzetli, zararsız, sıhhatli ve makbul gibi manalara gelirken; ${ }^{57}$ habîs ise kötü, pis, zararlı, şerli, iğrenç, zemmedilen fiil, günahkâr ve hain gibi anlamlarda kullanılmaktadır. ${ }^{58}$ Dolayısıyla pis ve iğrenç olan yiyeceklerin yanı sıra, mahiyeti veya neticesi itibarıyla zarar ve mefsedetin ortaya çıkmasına sebep olan nesne veya fiilleri de "habâis" çerçevesinde değerlendirmek mümkündür.

Konuyla ilgili Şatıbî'nin üzerinde durduğu; bir fiil veya nesnede zarar ve faydanın birlikte bulunması ve karşı karşıya gelmesi durumunda, bunlardan baskın olanın dikkate alınacağı ve hükmün ona göre verileceği; ${ }^{59}$ maslahat ve mefsedetin zamana, şahıslara ve şartlara göre değişmesi yönüyle itibarî olduğu; aynı şekilde fayda ve zarar değerlendirmesi yapılırken dünyanın ahirete

53 Karafî, el-Furûk, 1: 220.

54 en-Nisâ 4/29.

55 el-Bakara 2/195.

56 el-A'raf $7 / 157$.

57 Muhammed b. Mükerrem b. Manzûr el-Ensârî, Lisânüll-Arab, (Beyrut: Dâru sâdır), 1: 563; Murtaza Muhammed b. Muhammed ez-Zebidî, Tâcü'l-arûs min cevâhiri'l-kâmus, thk. Abdülhalim Tahâvî, (Kuveyt: et-Türâsü'l-Arabî, 2001), 3: 288.

58 İbn Manzûr, Lisânü'l-Arab, 2: 141; Zebidî, Tâcu'l-arûs, 5: 231-133.

59 İçki hakkında nâzil olan, "Sana şarap ve kumar hakkındaki hükmü sorarlar. De ki: İkisinde de hem büyük günah, hem de insanlara bazı menfaatler vardır. Fakat günahları faydalarından daha çoktur." (el-Bakara 2/219) ayeti de bu hükmü desteklemektedir. 
bakan yönüyle esas alınması gerektiği yönündeki yaklaşımları önem taşımaktadır. ${ }^{60}$

Özellikle teknik ve teknolojinin ilerlemesi ve endüstriyel yiyecek ve içeceklerin üretilmeye başlamasıyla birlikte helâl gıdanın önemli bir problem haline geldiği günümüzde, gıdaların hükmünü tespit etmede bu kâide önemli bir ölçü olacaktır. Modern araştırmacılar da helâl ve haram gıdaların tespit edilmesinde fayda-zarar kriterinin başvurulması gereken önemli kriterlerden birisi olduğunu ifade etmiş; sağlık açısından riskli olan ve insana zarar veren gıdaların caiz olmayacağını ifade etmişlerdir. ${ }^{61}$

\section{Haramı Meşrulaştırmak İçin Hileye Başvurmak da Haramdır}

İslâm, bir kısım fiillerin doğrudan ve açıkça işlenmesini haram kıldığı gibi, hakikat ve mahiyeti itibarıyla söz konusu yasakların çiğnenmesi manasına gelebilecek hile ve oyunları da yasaklamıştır. Hile, kişinin kendisine vacip kılınan bir hükmü düşürmek veya haram kılınan bir şeyi mubah kılmak için herhangi bir yolla girişimde bulunması ve bunun neticesinde şekil itibarıly kendisine vacip kılınan şeyin vaciplikten çıkması, haram kılınan şeyin de şeklen helâle dönüşmesidir. ${ }^{62}$ Hilenin mahiyet, şekil ve hükmüyle ilgili fukaha arasında oldukça farklı yaklaşımlar bulunsa da ${ }^{63}$ haramları mubah kılmak için hileye başvurmanın caiz olmadığı bizzat ayet ve hadislerle sabittir.

Yüce Allah, bu konuda haddi aşan İsrailoğullarının durumunu şu ifadelerle anlatmıştır: "İçinizden Cumartesi günü haddi aşanları elbette bilirsiniz. Biz böyle yapanlara 'Aşağılık maymun olun!' dedik."64 "Bir de onlara o deniz kıyısında bulunan şehir halkının başına gelenleri sor. Hani onlar Cumartesi gününün hükmüne saygısızlık edip Allah'ın koyduğu sınırı çiğniyorlardı. Şöyle ki, Cumartesi gününün hükmünü gözettiklerinde balıklar yanlarına akın akın geliyordu; Cumartesi gününün hükmüne riayet etmedikleri gün ise gelmiyordu. İşte fasıklıkları, yoldan çıkmaları sebebiyle onları böyle imtihan ediyorduk."65

60 İbrahim b. Musa b. Muhammed eş-Şâtıbî, el-Muvâfakât, thk. Ebu Ubeyde Meşhur b. Hasan Âli Süleyman, (Dâru İbn Affân, 1997), 3: 66-68.

61 Vehbe Zuhayli, Ahkâmu'l-mevâddi'n-necise ve'l-muharreme, (Dimeşk: Dâru'l-mektebî, 1997), 38-39; Abdullah Kahraman, "Gıda Ürünlerinde Helâl ve Haramı Belirleme Yöntemi", C. Ü. Illahiyat Fakültesi Dergisi 16, sy. 1, (2012): 466.

62 Bkz. Muhammed Tâhir b. Âşûr, İslâm Hukuk Felsefesi, çev. Vecdi Akyüz ve Mehmet Erdoğan, (İstanbul: Rağbet Yay., 2006), 180; Şâtıbî, el-Muvâfakât, 3: 124; Saffet Köse, "İslâm Hukukunda Kanuna Karşı Hile", (Doktora Tezi, Marmara Üniversitesi, 1993), 93-96.

63 Mezheplerin konuya yaklaşımıyla ilgili bkz. Saffet Köse, "Kanuna Karşı Hile”, 224-265.

64 el-Bakara 2/65.

65 el-Â'raf 7/163. 
İsrailoğullarına Cumartesi günü avlanma yasağı konulmuştu ve onlar bu yasağa uymak zorundaydılar. Ancak onlar avlanmanın yasaklandığı bu günde balıkların bolca geldiğini görünce, bu yasağı delme adına hileye başvurmuş ve o gün bol bol gelen balıkları özel hazırladıkları havuzlarda biriktirmişler, Pazar günü de gidip onları almışlardı. Her ne kadar görünüşte onlar balıkları Pazar günü elde etmiş olsalar da aslında avlanma yasağının delinmesi Cumartesi günü gerçekleşiyordu. Yani onlar Cumartesi günü balıkları havuzlara hapsediyor, onları yakalamayı garanti altına alıyor ve sadece onları havuzlardan almayı Pazar'a tehir ediyorlardı. Bu sebepledir ki onlar Yüce Allah'ın haram kıldığı bir şeyi elde etme adına zahirde meşru gibi görünen bir yol kullanarak, Allah'ın hükmünü bertaraf etmişlerdir. Çünkü onların bu uygulamalarıyla haram kılınan fiilin illeti ortadan kalkmıyordu. İşte zahirde meşru gibi görünse de hakikatte ona muhalif olan bütün hilelerin hükmü de aynen bunun gibidir. Zira Allah bu hâdiseyi zikretmekle koyduğu yasakları farklı yollardan çiğnemek suretiyle benzer şeylere tevessül etmemeleri noktasında Müslümanlara ders vermiştir. ${ }^{66}$

Benzer bir yasaklama da Sünnet'te bildirilmiştir. Resûl-i Ekrem, murdar hayvan ve şarabın yasaklandığını bildirdiğinde bazı sahabiler: "Ya Rasûlallah ölü hayvanların yağıyla gemiler yağlanır, onlar kandillerde kullanıIır. Biz de bu amaçla yağını kullanamaz mıyız?" demişler ancak Allah Rasulü bunun haram olduğunu ifade etmiş ve sonra da şöyle buyurmuştur: "Allah Yahudilere lânet etsin. Allah onlara iç yağını haram kıldığında onlar bunu erittiler, sonra sattılar ve ardından da bunun parasını yediler." ${ }^{67}$ Bu hadisten Allah'ın haram kıldığı şeyleri hileyle elde etmeye çalışmanın Allah'ın lânetine sebebiyet verdiği ve böyle bir kişinin de kendilerine gazap edilmiş olan Yahudilere benzeyeceği anlaşılmaktadır.

Hz. Peygamber, başka bir hadislerinde de haram kılınan bir maddenin semeninin de haram olacağını haber vermiştir. ${ }^{68}$ Demek ki İslâm, her ne şekilde olursa olsun haram kılınan bir nesneden istifade etmeyi yasaklamaktadır. Diğer bir ifadeyle haram kılınan bir nesneden doğrudan istifade etmek haram olduğu gibi, onun bedeli yerine geçen şeylerden istifade etmek de nehyedilmektedir. Zira bir şeyin bedeli aslının yerine kaim olur ve onun hükmünü alır. Çünkü haramlığın illeti, haram kılınan nesnenin hakikatine taalluk etmek-

66 Said Ramazan el-Bûtî, Davâbitu'l-maslaha fi'ş-şeriati'l-İslâmiyye, (Beyrut: Müessesetü'rrisâle, 1982), 295; Köse, "Kanuna Karşı Hile”, 295-296.

67 Buharî, "Büyû’”, 111; Müslim, "Müsâkât”, 71.

68 Ebû Dâvud, "İcâre”, 30; Ahmed b. Hanbel, el-Müsned, thk. Şuayb Arnavut, (Beyrut: Müessesetü'r-risâle, 1999), 4: 416; Dârakutnî, Sünen, 3: 7. 
tedir. Eğer haramlık hakikat, mahiyet ve sözün maksadına değil de görünüş ve şekline bağlı olmuş olsaydı, Yahudiler lânete uğramazlardı. ${ }^{69}$

Haram kılınmış bir maddenin ismini değiştirmek de onu helâl hale getirmeyecektir. Hz. Peygamber farklı hadislerinde bu duruma dikkat çekmiş ve insanların farklı isimler altında haramları irtikâp etmeye devam etmelerini ahir zaman alâmetlerinden birisi saymıştır. Konuyla ilgili bazı hadisler şöyledir: "Ümmetimden bazıları başka isimler altında mutlaka içki içeceklerdir. Onların başuçlarında çalgılar çalınacak ve kadınlar şarkı ve türkü söyleyeceklerdir. Allah onları yere batırsın ve onlardan domuz ve maymunlar yapsın."70 "Ümmetimden bazı topluluklar (değişik te'vil ve tefsirlerle) zina etmeyi, ipekli elbiseler giymeyi, içki içmeyi ve çalgılı eğlenceleri helâl sayacaklardır..."71; "Bu ümmet, nebiz (meşrubat) adı altında içkiyi, alışveriş adı alında faizi, hediye adı altında rüşveti helâl saydığı ve bir de zekâtı ticarete konu yaptığı zaman (yani sevabı ahirette görülecek zekât ibadetini, dünyevî çıkarları istikametinde kullandıkları zaman), işte bu onların helâki olur. Çünkü bu takdirde onların günahları iyice artar."72

Bu hadisler, Allah'ın haram kıldığı şeylerin isim ve suretlerinin değişmesiyle haramlık vasıflarının ortadan kalkmayacağını göstermektedir. Aynı zamanda burada, farklı te'vil ve tefsirlere giderek nikâh adı altında zina yapma, ziynet adı altında ipek giyme, hediye adı altında rüşvet verme, değişik isimler altında fuhuş yapma, alışveriş gibi gösterilerek faize girme gibi yollarla Allah'ın koyduğu yasakları çiğneyen kimseler zemmedilmektedir. Çünkü şayet isim ve şekillerin değiştirilmesiyle gerekçe ve hükümler de değişseydi din tahrip olurdu. Dolayısıyla bu hadisler isimlerin değiştirilmesiyle hükümlerin değişmeyeceğine delil teşkil etmektedir. Zira hükümler, muamelelerin dış görünüşüne değil, mana ve maksatlarına bağlıdır.

\section{Harama Götüren Vesileler de Haramdır}

İslâm, haram kıldığı şeylere götürebilecek vesile ve sebepleri de yasaklamak suretiyle, haramlardan uzak kalınması adına uygun ortamı hazırlamıştır. Diğer bir ifadeyle İslâm, sadece nehyedilmiş fiilleri irtikâp eden kimselere belli cezaları öngörmekle yetinmemiş, bunun yanında daha baştan harama götürebilecek yolları da yasaklamıştır. Sözgelimi zinayı haram kılan ayet, "Zi-

69 Köse, "Kanuna Karşı Hile", 295; 307.

70 Nesâî, "Eşribe", 41; İbn Mâce, "Fiten", 22.

71 Buharî, "Eşribe", 6; Ebû Dâvud, "Libâs", 6.

72 Alâuddin Ali b. Hüsamüddin el-Müttakî, Kenzü'l-ummâl fî süneni'l-akvâli ve'l-ahvâl, thk. Bekrî Hayyânî, (Beyrut: Müessesetü'r-risâle, 5. baskı, 1981), 14: 226. 
naya yaklaşmayın."73 şeklinde gelerek, sadece zina fiilini işlemeyi değil, kişiyi zinaya sürükleyebilecek, halvet, ihtilât, açık saçıklık gibi bir kısım sebepleri de yasaklamıştır. Aynı şekilde Allah Resûlü, içki içmenin yasak olmasının yanında, onu sıkma, sıktırma, servis yapma, taşıma, satma, satın alma, parasını yeme gibi davranışların da Allah'ın gazabını celbedeceğini ifade etmiştir. ${ }^{74}$

Usulcüler, dinî hükümleri maksatlar ve vesileler şeklinde ikili bir taksime tâbi tuttuktan sonra, vesilelerin hükmünü ifade etme sadedinde şöyle

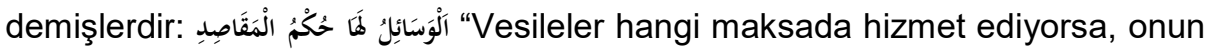
hükmünü alır."75 Buna göre, namaz, cenaze teşyîi veya sıla-i rahim gibi bir ibadet için yolculuk yapan kimsenin bu yolculuğu da ibadet sayılacağı gibi; içki içme veya hırsızlık yapma gibi haram bir fiili işlemek için yola çıkan kimsenin yolculuğu da haram olacaktır. Çünkü bu kişinin attığı her adım onu harama götürmektedir.

Fer'î deliller arasında yer alan sedd-i zerâî delili de temelde bu usul kuralına dayanmaktadır. Çünkü asıl itibarıyla mubah olan bir davranış, kat'î olarak veya zann-ı galip ile harama götürecekse, sedd-i zerâî delili gereğince bunun yapılması da yasak olmaktadır. Diğer bir ifadeyle, fesad, mefsedet ve münkere ulaştırması kuvvetle muhtemel olan meşru fiiller de neticeleri itibarıyla gayr-i meşru sayılmışlardır. ${ }^{76}$ Müşriklerin haddi aşarak Allah'a hakaret etmemeleri için onların Allah'tan başka yalvardıkları tanrılara hakaret etmenin yasaklanması, ${ }^{77}$ mü'min kadınların gizli ziynet ve güzelliklerinin erkekler tarafından dikkat çekmemesi için onların ayaklarını yere sert vurarak yürümelerinin nehyedilmesi, ${ }^{78}$ karı-kocanın mahremiyetlerine muttali olmamaları için kölelerin ve ergenlik çağına ulaşmamış çocukların günün belli vakitlerinde içeri girmek için izin istemelerinin emredilmesi, ${ }^{79}$ Cuma namazına mâni olabileceği için Cuma vaktinde alışverişin yasaklanması, ${ }^{80}$ bir kısım tehlikelere maruz kalmaması için kadınların yanlarında mahremi bulunmadan yolculuğa

73 el-ìsrâ 17/32.

74 Bkz. Hâkim, el-Müstedrek, 4: 145; Beyhakî, es-Sünenü'l-kübrâ, 8: 287.

75 İzzüddin Abdülaziz b. Abdisselam b. Ebi'l-Kasım b. Hasan, Kavâidü'l-ahkâm fî mesâlihi'lenâm, thk. Mahmud b. et-Telâmîd eş-Şenkîtî, (Beyrut: Dâru'l-ma'rife), 46; Necmüddin Ebu'rRabi' Süleyman b. Abdilkavî b. Kerim et-Tûfî, Şerhu muhtasari'r-ravda, thk. Abdullah b. Abdilmuhsin, Müessesetü'r-risâle, (Beyrut, 1987), 3: 89.

76 Bkz. Muhammed Hişâm el-Burhânî, Seddü'z-zerâi' fi'ş-şerîati'l-İslâmiyye, (Dimeşk: Dâru'l-fikr, 1995), 80-84.

77 el-En'âm 6/108.

78 en-Nûr 24/31.

79 en-Nûr 24/58.

80 el-Cum'a 62/9. 
çıkmalarının nehyedilmesi ${ }^{81}$ gibi Kur'ân ve Sünnet'te sedd-i zerâî delilinin meşruiyetini gösteren pek çok nass bulunmaktadır.

İbn Kayyim el-Cevziyye'nin, maksada götüren vesilelerin hükmüyle ilgili yapmış olduğu şu izahlar konunun anlaşılması adına oldukça önemlidir: "Eğer maksatlara sadece belirli sebep ve yollarla ulaşılabiliyorsa, söz konusu sebep ve yollar da maksada tâbî olur ve ona göre değerlendirilir. Buna göre haram ve günahların vesileleri, gayeye ulaştırması ve onunla irtibatına göre çirkin görülecek ve yasaklanacaktır. Aynı şekilde ibadet ü taatin vesileleri de gayeye ulaştırması ölçüsünde güzel görülecek ve bunlara müsaade edilecektir. Yüce Allah, bir şeyi haram kıldığı zaman, bu emrinin yerine getirilmesi, perçinlenmesi ve ona yaklaşılmasının yasaklanması için, bu harama ulaştıran yol ve vesileleri de haram kılar ve onlardan men eder. Şayet Allah, harama götüren yol ve araçları mubah kılmış olsaydı, hiç şüphesiz bu, haram kılma iradesiyle bir çatışma ve insanları harama teşvik etme anlamına gelirdi. Hâlbuki Allah'ın ilim ve hikmeti böyle bir tavırdan tamamıla beridir." ${ }^{2}$

İbn Kayyim, söz konusu hakikatin daha iyi anlaşılması ve zihinlere daha iyi yerleşmesi adına beşerî düzenlemelerden de misaller vermiş ve onların da aynı tarzda gerçekleştiğini açıklamıştır. O, sözlerine şöyle devam etmiştir: "Bırakalım Allah'ın ilim ve hikmetini, hükümdarların idare şekli bile böyle bir hareket tarzına aykırıdır. Zira herhangi bir hükümdar, askerlerini, teb'asını veya ailesini bir şeyden men eder fakat ona ulaştıran sebep ve yolları serbest bırakırsa, kendisiyle çelişkiye düşmüş sayılır ve bu durumda askerleri veya teb'ası onun maksadına aykırı işler yapar. Benzeri bir durum doktorlar için de söz konusudur. Onlar bir hastalığı tedavi etmek istediklerinde, hastayı bu hastalığa götürecek sebep ve araçlardan men ederler. Aksi takdirde hastayı iyileştirme adına attıkları adımlar boşa gider. Beşer hayatında bile durum böyleyken, hikmet, maslahat ve kemal açısından en yüksek mertebede bulunan şeriat alanında öncelikli olarak aynı ilkenin geçerli olması gerekmez mi? Her kim şeriatın kaynakları ve delilleri üzerinde dikkatli bir inceleme yapacak olursa, Allah ve Resûlü'nün haram kılmak ve yasaklamak suretiyle haramlara götüren yolları da kapattığını anlayacaktır."83

Herhangi bir fiil, fıkhî açıdan hükme bağlanırken, onun sebep olduğu veya ortaya çıkardığı sonuçların dikkate alınması gerektiği anlayışını ortaya

81 Buharî, "Hac", 204; Müslim, "Hac", 74.

82 İbn Kayyim el-Cevziyye, l'lâmü'l-muvakiîn an Rabbi'l-âlemîn, (Dimeşk: Dâru'l-kütübi'l-ilmiyye, 1991), 3: 109.

83 İbn Kayyim, I'lâmü'l-muvakiîn, 3: 109. 
koyması ve daha işlenmeden haramların önüne geçmesi açısından sedd-i zerâî kavramı fıkıhta önemli bir yere sahip olsa da; söz konusu vesile ve sebepler ile neticeler arasındaki ilişki ve bağ iyi tespit edilemez ve sağlam ölçülere bağlanamazsa, bunun keyfî bir kısım değerlendirmelere, temel hak ve özgürlüklerin ihlaline, birey ve topluma zarar veren sonuçların ortaya çıkmasına sebep olabileceği gözden kaçırımamalıdır. ${ }^{84}$

\section{Harama Düşmemek İçin Şüpheli Şeyler Terkedilmelidir}

Mahiyeti itibarıyla mubah olmasına ve bizatihi mefsedet ve zarar içermemesine rağmen harama götürmesi kesin veya kuvvetle muhtemel olan fiiller sedd-i zerâi' ilkesi gereğince nehyedildiği gibi; helâl ve haram olma ihtimali bulunan ve hükmü hakkında net bir neticeye varılamayan şüpheli fiillerden uzak durulması da konuyla ilgili pek çok hadisten çıkarılan bir esastır. Şüpheli şeylerden uzak durmaya çağıran en önemli hadis şudur: "Helâl olan şeyler de haram olan şeyler de bellidir. Bu ikisinin arasında, her ikisine de benzeyen bir kısım şüpheli şeyler vardır ki insanların çoğu bunları bilmez. Her kim ki bu şüpheli şeylerden sakınırsa, dinini ve ırzını korumuş olur. Şüpheli alanda dolaşan kimse ise bir korunun kenarında hayvanlarını otlatan çoban gibidir. Nasıl ki bu hayvanların her an koruya girmesi muhtemelse (şüpheli alanda dolaşan kimsenin de haramları işlemesi öyle muhtemeldir.) Biliniz ki her melikin bir korusu vardır; Allah'ın yeryüzündeki korusu da haramlarıdır." 85 Konuyla ilgili diğer bir hadiste ise $\mathrm{Hz}$. Peygamber şöyle buyurmuştur: "Seni kuşkuya düşüren şeyleri terk ederek, seni şüphelendirmeyen şeylere geç."

Şüphe, şer'i bir hüküm, konu ya da durumla ilgili kesin bilgi ve kanaate ulaşamamadan dolayı ortaya çıkan tereddüt ve kararsızlığı ifade eden bir kavramdır. Şüpheyle ilgili, "Helâl ile haramın birbirine karışması", "Helâl mi haram mı olduğu kesin olarak belli olmayan/bilinemeyen şey", "Aralarındaki benzerlikten dolayı, iki şeyden birinin diğerinden ayırt edilememesi" şeklinde tanımlar da yapılmıştır. Şüpheli konularda başka hiçbir delilin bulunmaması durumunda intiyata göre amel edilerek şüpheden uzak durulacağı ifade edilmiştir. Zira şüpheli konularda intiyatî bir tutum ortaya koyan mükellef, dinî mükellefiyetler karşısındaki sorumluluğundan kesin olarak kurtulmuş olacaktır. Mesela hem mubah hem de haram olma intimali bulunan bir meselede, mükellefin haram olma intimalini dikkate alarak ondan uzak durması; şayet o şey

84 İbrahim Kâfi Dönmez, "Sedd-i Zerâi', Türkiye Diyanet Vakfı İslâm Ansiklopedisi, c. 36, (İstanbul: TDY Yay., 2009), 282.

85 Buharî, "Îmân”, 39; "Büyû’”, 2; Müslim, "Müsâkât”, 107, 108.

86 Buharî, "Buyû́”, 3; Tirmizî, "Kıyâmet”, 60. 
gerçekte haram ise onu bir haramı irtikâp etmekten kesin olarak kurtarmış olacaktır. Söz konusu meselenin mubah olması durumunda ise mükellef için bir vebal bulunmayacaktır. Böylece intiyatlı davranmak, mükellefin kalben tatmin olmasını temin etmiş olacaktır. ${ }^{87}$

İmam-ı Gazzâli, helâl ve haramların da kendi içinde muhtelif dereceleri olduğunu ifade ettikten sonra haramdan sakınmanın dört farklı derecesi bulunduğunu ifade etmiştir. Bu dereceler şunlardır:

1- Adil kimselerin veraı: Fukahanın fetvalarında açıkça haram olduğunu ifade ettikleri şeylerden uzak durmaktır. Yoksa bunları ihlal eden kimse fıska girmiş olacağından onun adalet vasfı da düşecektir. Aynı zamanda bununla kişi bir isyan içine girdiğinden cehennem ateşine müstehak olacaktır.

2- Salih insanların veraı: Genel manada şüphe mahallerinden uzak durmadır. Müftüler, zahire bakarak bazı şeylere fetva vermiş olsalar da az da olsa bunlarda haramlık ihtimali bulunduğundan dolayı, salih kimselerin vera gereği bunlardan da sakınması gerekir. Gazzâli, genel manada şüpheli şeylerden sakınmanın müstehab olduğunu söylese de bazı şüpheli şeylerin haram derecesinde görüldüklerini, bunlar hakkında haram gibi muamele yapılması gerektiğini ve dolayısıyla da bunlardan sakınmanın vacip olacağını ifade etmiştir.

3- Yakîn erbabının veraı: Haklarında ne haramlık fetvası ne de helâl olduklarında şüphe bulunmayan şeylerin, sırf bir haramı irtikâp etmeye götüreceğinden korkularak terk edilmesidir.

4- Sıddıkların veraı: Yapılmasında hiçbir beis olmayan ve yapılmasıyla beis olan bir şeye de sebep olmayan hususların bile değişik mülahazalardan dolayı terk edilmesidir. Bu makamda bulunanlar, Allah için olmadığını bildikleri bütün masivaullahı kendileri için yasak kabul ederler. Onların tek gayesi Allah rızasını kazanmaktır. ${ }^{88}$

Helâl ve haramlığı açık olan meseleler arasında yer alan şüpheli şeyleri tespit etme ve bunlardan kaçınma mevzuunda; araştırma yapmak, işaret ve karinelerden yola çıkmak, ihtilaf alanlarından uzak durmak, ihtiyatı esas almak, istishaba göre hareket etmek gibi bazı çözüm yolları olsa da yine de bu tür konularda insanın nasıl bir tavır alması gerektiğiyle ilgili objektif ve kesin ölçülerden bahsetmek zordur. Şüpheli şeylerin alanını tespit etme sade-

\footnotetext{
87 Ali İhsan Pala, İslâm Hukukunda İhtiyat İlkesi, (Ankara: Fecr Yay., 2009), 45-46; 262-263.

88 Ebû Hâmid Muhammed b. Muhammed el-Gazzâlî, Ihyâu ulûmi'd-dîn, (Beyrut: Dâru'l-mâ'rife), 3: 94-95.
} 
dinde, "delillerin tearuz ettiği şey", "ulemanın ihtilafa düştüğü mevzu", "helâl veya haram olduğuna dair kesin bir hükmün bulunmadığı mahal" gibi farklı yaklaşımlar bulunsa da kanaatimizce nelerin şüpheli olup olmadığı ve bunlardan nasıl uzak durulacağı mevzuunda, fertlerin bilgileri ve kanaat-i vicdaniyeleri de önemli bir rol oynamaktadır. Serahsî de, "Ulema arasında ihtilaflı olsa bile insanın caiz olduğuna itikat ettiği şeyleri yapmasında bir beis yoktur. Böyle bir davranış dinde intiyatlı olanı terk manasına da gelmez. ${ }^{89}$ ifadeleriyle kanaat-i vicdaniyenin önemine dikkat çekmiştir. Buna göre mükellefler için şüpheli şeyler konusundaki önemli bir çözüm yolu da kalbin fetvasına başvurmaktır. Çünkü kalb, hadisin ifadesiyle iyilikten huzur ve itmi'nan, günahtan ise rahatsızlık duyar. ${ }^{90}$ Ayrıca Resûlüllah da kesin bir nassın olmadığı, farklı içtihatların bulunduğu ve harama girme korkusunun söz konusu olduğu yerlerde intiyatlı hareket etmeye işaret sadedinde "Müftüler fetva verse de, sen bir de kalbinden fetva sor." ${ }^{11}$ beyanıyla bu hususa işaret etmiştir.

Başka bir hadiste ise Hz. Peygamber (s.a.s) kendisine iyilik ve günah hakkında soru sormaya gelen Vâbısa b. Ma'bed'e hitaben şöyle buyurmuştur: "Ey Vâbısa, insanlar sana fetva vermiş olsa da sen bir de nefsinden fetva iste. İyilik kalbin ve nefsin kendisiyle itmi'nana erdiği şeydir. Günah ise kalbi sıkıntıya sokan ve gönülde tereddüt hâsıl eden şeydir." ${ }^{22} \mathrm{Bu}$ hadis hakkında İbn Recep şunları söylemiştir: "Vâbısa hadisi ve onunla aynı manadaki diğer hadisler şüphe durumunda kalbe müracaat edilmesi gerektiğine delâlet etmektedir. Bu durumda kalbin sükûna erdiği ve gönlün inşirah bulduğu bir şey, iyiliktir, helâldir."93

Şüpheli şeylerden kaçınma, biraz da fertlerin iman ve takva derinliğiyle yakından alakalı olduğundan, meselenin göreceli ve subjektif bir yönü bulunmaktadır. Fakat şahıslar haramlara düşmeme adına şüpheli şeyleri terk konusunda kendileri hakkında ne kadar titiz ve hassas davranırsa davransınlar, hiçbir zaman başkalarını buna mecbur tutmamalı, helâl ve haramlar hakkında umum fertler için geçerli olanın, objektif hükümler olduğunu unutmamalıdırlar.

89 Şemsüleimme Muhammed b. Ahmed es-Serahsî, Kitâbu'l-mebsût, (Beyrut: Dâru'l-ma'rife), 23: 13.

90 Bkz. Müslim, "Birr", 14; Tirmizî, "Zühd”, 52; Ahmed b. Hanbel, el-Müsned, 29: 533.

91 Suyûtî, el-Fethu'l-kebîr fî dammi'z-ziyâdeti ile'l-Camii's-sagîr, thk. Yusuf en-Nebhânî, (Beyrut: Dâru'l-fikr, 2003), 1: 66; Ali el-Müttakî, Kenzü'l-ummâl, 10: 250.

92 Ahmed b. Hanbel, el-Müsned, 29: 527-528.

93 Abdurrahman b. Ahmed b. Receb el-Hanbelî, Câmiu'l-ulûm ve'l-hikem, (Beyrut: Dâru'lma'rife, 1408), 1: 254 
Öte yandan şüpheli şeylerden kaçınma mevzuunda da işi vehim ve vesveseye vardıracak derecede aşırıya gitmek doğru değildir. Çünkü Resûl-i Ekrem üç defa arka arkaya: "Dikkat edin! Aşırı gidenler helak oldular." ${ }^{94}$ buyurmak suretiyle, Müslümanları bütün işlerinde ifrat ve tefrite düşmeme konusunda ikaz etmiştir. Buna göre şüpheden bahsedebilmek için, haramlık şüphesini gerektirecek bir delil, sebep veya emare olması gerekir. Mesela bir Müslüman, hiçbir delile dayanmaksızın başka bir Müslüman'ın yemeğini "şüphelidir" korkusuyla yemezse, onun hakkında su-i zana girdiğinden dolayı haram işlemiş olacaktır. Çünkü bir insanın Müslüman olması onun yiyeceğinin helâl olması açısından bir karinedir. Aksi bir delil bilinmediği sürece onun yemeğinin helâl olduğu kabul edilir. Zira bir delilden kaynaklanmayan intimale itibar edilmeyeceği önemli bir fıkıh kâidesidir. ${ }^{95}$

\section{Helâl ve Haram Bir Arada Bulunduğunda Haramlık Yönü Tercih Edilir}

Helâl ve haramlar alanında geçerli olan ve pek çok güncel meselenin çözümünde başvurulabilecek olan diğer bir kâide de bir mesele hakkında helâl ve haram kılıcı delilin veya helâl ve haram kılıcı vasfın ya da helâl ve haram kılıcı sebebin birlikte bulunduğu, bunlardan birinin helâlliğe diğerinin de haramlığı delâlet ettiği ve delillerin kuvveti açısından bunlardan birisini diğerine tercih etmenin mümkün olmadığı durumlarda, haramlık cihetinin tercih edilerek söz konusu meselenin haramlığına hükmetmektir. ${ }^{96}$

Özellikle bugün ortaya çıkan pek çok meselede helâl ve haram karışık halde bulunduğundan dolayı, mükelleflerin zihninde tereddüt ve şüpheler hâsıl olmaktadır. Hâlbuki şer'î açıdan bir şeyin aynı anda hem haram hem de helâl olması gibi bir durum söz konusu olamaz. ${ }^{97}$ Çünkü helâl ve haram birbirinin zıddı olan iki şer'i hükümdür. Şeriatta aynı anda bir mahalde bir cihetten birbirine zıt iki hükmün bir arada bulunması mümkün değildir. Ayrıca böyle bir durumun kabul edilmesi Şari Teâlâ'nın bir şeyde aynı anda iki zıt hükmü birden murad ettiği manasına gelir ki ahkâm-ı ilahîde böyle bir durum tasavvur edilemez. Zira mükellefler açısından da birbirine zıt iki hükümle aynı anda amel etmek teklif-i mâlâ yutaktır. Bu itibarladır ki aslında bir şeyde hem helâl

\footnotetext{
94 Müslim, “ilim”, 7; Ebû Dâvud, "Sünnet”, 7.

95 Bk. Mecelle, md: 73.

96 Yahya Musa, el-Kavâidu'l-fıkhiyye, 55.

97 Serahsî şöyle demiştir: "Bir mahalde iki zıt hükmün aynı anda bir arada bulunması imkânsız olduğundan dolayıdır ki, bir mahalde haramlık sıfatının sabit olması için, helâllik sıfatının zail olması şarttır." (Serahsî, el-Mebsût, 6: 71)
} 
hem de haramlık cihetinin olduğunun zannedilmesi, hakikatte değil, müctehidin zahiri nazarında vuku bulan bir hâdisedir. Dolayısıyla konuyla ilgili diğer delillerin değerlendirilmesinin yanında, zikredilen bu kâide de fukahanın bir hükme varmasında tercih ettirici bir delil olmaktadır. ${ }^{98}$

Beyin ölümü gerçekleşen kimsenin hayatına son verme, ölü veya diri olan bir insandan başka bir insana organ nakletme, tüp bebek uygulaması, süt bankalarının kurulması gibi pek çok güncel meselenin fıkhî bir çözüme kavuşturulmasında kullanılabilecek olan bu kâide, günümüzde özellikle helâl ve haramlığında şüphe bulunan gıdalarla ilgili problemlerin çözümünde de önemli bir asıl olarak karşımıza çıkmaktadır. Fakat bu kâidenin bir meseleye uygulanabilmesi için helâl ve haramın aynı kuvvette olması ve birisini diğerine tercih ettirici başka bir faktörün bulunmaması ya da haramın daha galip olması gerekmektedir. ${ }^{99}$

Hususiyle kavaid alanında kitap yazan çok sayıda İslâm hukukçusu, farklı lafızlarla ilgili kâideye yer vermiş ve örnek olması açısından da bu kâidenin altında yer alan bazı füru meseleleri ele almışlardır. ${ }^{100}$ Söz konusu kâideyle ilgili kullanılan bazı lafızlar şu şekildedir: "Helâl ve haram bir arada bulunduğunda, haram ağır basar."; 101 "Haram ve helâl kılıcı delil ictima ettiğinde, haram kılıcı delil galebe eder."102 "Haramlığı gerektiren bir delil ile mubahlığı gerektiren bir delil tearuz ettiğinde, haramlık yönünü baskın kılmak için yasak ciheti tercih edilir.", 103 "Helâl ve haram bir mahalde ictima ettiklerinde, başta ve sonda haramlık yönü ağır basar.", 104 "Helâl ve haram eşit olduğu zaman, haram, helâlin önüne geçer." 105 "Helâl ve haram birbirine karıştığında, helâlden kaçınmak vacip olur."106

Helâl ve haram kılıcı delil, sebep veya vasfın birlikte bulunduğu ve bunlardan birisini diğerine tercih etme imkânının kalmadığı meselelerde haramlık yönünün tercih edilmesinin altında yatan en önemli düşünce, ihtiyat

\footnotetext{
98 Bkz. Şâtıbî, el-Muvafakât, 5: 341-342

99 Musa, el-Kavâidu'l-fıkhiyye, 30; 79.

100 Bkz. Bedrüddin Muhammed b. Bahadır ez-Zerkeşî, el-Mensûr fi'l-kavâid, thk. Teysir Fâik Ahmed Muhammed, (Kuveyt: Vizâretü'l-evkâf ve'ş-şuûni'l-İslâmiyye), 1: 125; Suyutî, el-Eşbâh ve'n-nezâir, 1: 105; İbn Nüceym, el-Eşbâh ve'n-nezâir, 1: 109.

101 İbn Nüceym, el-Eşbâh ve'n-nezâir, 1: 109; Suyutî, el-Eşbâh ve'n-nezâir, 1: 105.

102 Zerkeşi, el-Mensûr fi'l-kavâid, 1: 125; İbn Nüceym, el-Eşbâh ve'n-nezâir, 1: 109

103 Zerkeşi, el-Mensûr fi'l-kavâid, 1: 125

104 Serahsî, el-Mebsût, 6: 90.

105 Serahsî, el-Mebsût, 3: 157.

106 Zerkeşi, el-Mensûr fi'l-kavâid, 1: 132.
} 
ilkesidir. Aynı zamanda istikra metoduyla anlaşılmaktadır ki fakihler tearuz ve tercih bahislerinde pek çok fer'î meselenin çözümünde bu kâideyi kullanmıştır. Önemli bir fıkhî kâide olan, def-i mefâsidin, celb-i menâfiden evlâ olması da, şeriatta haramların terk edilmesinin öncelikli olduğunu göstermektedir. ${ }^{107}$ Zira Şâri Teâlâ'nın haramların terk edilmesine verdiği önemin, farzların işlenmesine gösterdiği önemden daha büyük olduğu ifade edilmiştir. ${ }^{108}$

Genel itibarıyla haramın irtikâp edilmesinin farz olmasına mukabil, helâlin yapılmasının mubah olması düşüncesi de bu kâidenin vücut bulmasında etkili olmuştur. Çünkü farz ve mubahtan birisinin tercih edilmesi gereken bir mahalde, bu iki hüküm arasında tearuzun vuku bulması imkânsız olduğu için farzın/haramın terkinin ağır basacağı açıktır. ${ }^{109}$

Ayrıca Hz. Peygamber'in Adiy b. Hâtim'e ifade buyurduğu şu sözleri de bu kâidenin dayanmış olduğu önemli bir delildir: "Şayet köpeğini avın üzerine saldın ve besmele de çektiysen, köpeğin yakalayıp öldürdüğü avı ye. Şayet köpeğin avdan yediyse, ondan yeme. Çünkü bu durumda köpek avı kendisi için tutmuştur. Şayet (senin köpeğin) Allah'ın ismi zikredilmeden gönderilmiş köpeklerle karışır ve bunlar hep birlikte bir av yakalayıp öldürürlerse, bu avdan yeme. Çünkü sen bu köpeklerden hangisinin avı öldürdüğünü bilemezsin. Aynı şekilde şayet sen okunla bir av vurur da, bu avı bir veya iki gün sonra bulursan ve avın üzerinde senin okundan başka bir yara da yoksa ondan ye. Şayet av bir suya düştüyse ondan yeme."110 Müslim'de şu ilâve vardır: "Sen avı suyun mu yoksa okunun mu öldürdüğünü bilemezsin."111

Yukarıdaki hadiste Allah Resûlü'nün, besmele çekilerek gönderilmiş köpeklerle besmele çekilmeden gönderilmiş köpeklerin beraber tuttuğu veya vurulduktan sonra suyun içine düşen bir avın yenilmemesini emretmesinin sebebi, bu av hayvanlarının ölüm sebebinin kesin olarak helâl yollardan gerçekleştiğinin bilinmemesidir. Bu hayvanların ölüm sebeplerinde, helâl ve haram her iki intimalin de bulunmasına rağmen Allah Resûlü'nün haramlık yönü-

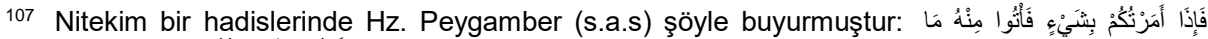

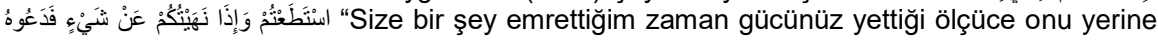
getirin. Size bir şeyi nehettiğim zaman ise derhal onu bırakın." (Müslim, "Hac", 412) Allah Resûlü, burada emredilen şeylerin yerine getirilmesini mükellefin güç yetirebilmesine bağlamıştır. Çünkü bir fiilin yerine getirilmesinde insanların takatleri farklı farklıdır. Fakat bir yasağın terk edilmesi bir şarta bağlanmamış ve nehiyle birlikte derhal ondan uzak durulması emredilmiştir.

108 Suyûtî, el-Eşbâh ve'n-nezâir, 1: 87.

109 Musa, el-Kavâidu'l-fıkhiyye, 81.

110 Buharî, "Zebâih", 8;

111 Müslim, "Sayd", 7.

ÇÜiFD, 2018, cilt: 18, sayı: 1, ss. 597-633 
nü tercih etmesi, şüpheli şeylerden kaçınma, ihtiyatı esas alma ve haramlık cihetinin tercih edilmesi gibi ilkelerin meşruiyetini göstermektedir.

Bununla birlikte bu kâidenin bazı istisnaları olduğu unutulmamalı ve bu kâide fer'î meselelere uygulanırken, ibaha-i asliyye ilkesiyle birlikte düşünülmelidir. Yani bu kâidenin mutlak olarak düşünülüp her meseleye uygulanmaya çalışılması isabetli bir yaklaşım değildir. Çünkü pek çok fıkhî kâidede olduğu gibi bu kâidenin hükmü de küllî olmayıp ekseriyet itibarıyladır. Ayrıca bu kâidenin uygulanmasıyla ilgili fakihler arasında bazı ihtilâfların bulunduğu da unutulmamalıdır.

\section{8. İyi Niyet Haramları Mubah Kılmaz}

Hz. Peygamber, "Ameller ancak niyetlere göredir ve herkesin niyeti ne ise eline geçecek odur." 112 buyurmak suretiyle, İslâm'ın kasıt ve niyete ne kadar çok ehemmiyet verdiğini göstermiştir. Öyle ki bir ibadetin Allah katında kabul olması, onun halis bir niyetle eda edilmesine bağlıdır. Halis niyet ise bir amelin başka değil sadece Allah rızası için yapılmasıdır. Kişinin niyetine göre günlük iş ve amellerinin bile ibadet hükmünü alacağı ifade edilmiştir. ${ }^{113}$ Fakat haramlar alanında iyi niyetin bir tesiri yoktur. Yani kişinin kastı ve niyeti ne kadar iyi olursa olsun, maksat ve hedefi ne kadar yüce olursa olsun yine de haramları mubah kılmaz.

Başkalarına riya ve gösteriş için bile olsa bir haramı işlemeyen kimse günaha girmez. Çünkü ortada haram bir fiil yoktur. Aynen bunun gibi bir kimse hangi maksat ve niyetle haram bir fiili işlerse işlesin, söz konusu fiil yine de haramdır. Mesela bir kimse Müslümanlara yardım etmek, hayır hasenat yapmak gibi yüce gayeler peşinde olsa bile, bu gayelere ulaşmak için kumar oynama, içki ticareti yapma, tefeciliğe bulaşma gibi gayr-i meşru yolları kullanamaz. Aynı şekilde bir insanın kendine göre makul sayılabilecek farklı teviller bularak haram kılınan gıdaları tüketmesi de caiz değildir. Bu sebepledir ki İslâm, maksada götüren her vesileyi meşru sayan makyavelist düşünceye karşı çıkmış ve insanı meşru bir hedefe ulaştıran vesile ve yolların da meşru olması gerektiğini hükme bağlamıştır. Diğer bir ifadeyle İslâm'da gaye ve hedeflerin meşru olması gerektiği gibi, söz konusu gaye ve hedefe ulaşmak için kullanılan vesilelerin de aynı şekilde meşru olması gerekir.

112 Buharî, "Bed'u'l-vahy", 1; Müslim, “İmâra”, 155.

113 Karaman, Günlük Hayatımızda Helâller ve Haramlar, 24. 


\section{Zaruretler Haramları Mubah Kılar}

Zaruret lügat manası itibarıyla, zorunluluk, şiddetli sıkıntı, bir şeyi yapmaya mecbur olmak ve intiyaç gibi manalara gelmektedir. ${ }^{114}$ Zaruretin ıstılahî manasıyla ilgili olarak ilk dönemden itibaren farklı tanımlar yapılmıştır. Mesela Cessas, zarurete dair şu tarifi getirmiştir: "Zaruret, yemeyi terk etmekten dolayı, nefsine veya bazı uzuvlarına bir zarar gelmesi korkusudur."115 Zerkeşi'nin şu tarifi de buna yakındır: "Zaruret, muzdarın öyle bir sınıra ulaşmasıdır ki şayet yasaklanan şeyi almazsa, ya helâk olur ya da helâka yaklaşır. Yemeye ve giymeye mecbur kalan kimse gibi ki aç veya çıplak olarak kalsa bu kimse ya ölecek veya bir uzvu helâk olacaktır."116 Cürcânî ise zaruret için şu veciz tarifi yapmıştır: "Zaruret, insanın def etme imkânı olmayan bir tehlikeye maruz kalmasıdır."117 Vehbe Zuhayli'nin yaptığı şu tarif ise daha geneldir: "Zaruret, insanın nefis, uzuv, ırz, akıl, mal veya bunların tâbilerine bir zararın veya eziyetin gelmesinden korkulan tehlike veya şiddetli meşakkatle karşılaşma hâlidir."118

İlk dönem fakih ve usulcülerinin zaruretle ilgili yaptıkları tarifler daha çok açlık veya susuzluktan dolayı nefsin helâkine dairdir. Yani zaruret meselesinin genellikle muzdar durumdaki kişinin neleri yiyip içebileceğine dair hükümler işlenirken ele alındığını görüyoruz. Farklı bir ifadeyle ilk dönem kaynaklarında daha çok hangi zaruret hâllerinin haram kılınan gıdaları mubah kılacağı üzerinde durulmuştur. Bunun önemli bir sebebi, zaruretle ilgili ayetlerin bu siyakta varit olmasıdır. Fakat nefsin helâkini önlemek için haramlardan istifade etmek, zaruretin sadece bir çeşidini oluşturmaktadır. Vehbe Zühayli'nin tarifinde de görüldüğü üzere, nefse gelecek bir zararın yanında, mala, akla veya ırza gelecek zararlar da şartlarına göre zaruretin kapsamına girecektir. Ayrıca zaruret açlık, susuzluk ve hastalık gibi kendiliğinden meydana gelebileceği gibi, başkasının zorlamasıyla da tahakkuk edebilir.

İslâm hukukunun bütün alanlarında etkili olan ve bazen haramları mubah hale getiren bazen de vacip olan fiillerin terk edilmesini caiz kılan zaruret hali, kişiyi helâke sürükleyecek derecede aşırı açlık ve susuzluk hallerinde

\footnotetext{
114 İbn Manzur, Lisânü'l-Arab, 4: 482; Zebidî, Tâcu'l-arûs, 12: 388.

115 Ebû Bekir Ahmed b. Ali el-Cessâs, Ahkâmu'l-Kur'ân, thk. Abdüsselam Muhammed Ali Şâhin, (Beyrut: Dâru'l-kütübi'l-ilmiyye, 1994), 1: 157.

116 Zerkeşî, el-Mensûr fi'l-kavâid, 2: 319.

117 Ali b. Muhammed es-Seyyid eş-Şerif el-Cürcânî, Ta'rifât, thk. İbrahim el-Ebyârî, (Beyrut: Dâru'l-kütübi'l-Arabî, 1405), 1: 180.

118 Vehbe Zühayli, Nazariyyetü'd-darûreti'ş-şer'iyye mukâranetün maa'l-kanûni'l-vad'iyyi, Müesse-setü'r-risâle, (Beyrut, 1982), 67-68.
} 
de haram kılınan gıdaları geçici süreyle helâl hale getirir. Aslında bir haramı irtikâp etmek önemli bir zarardır. Fakat kişinin hayatının veya bir uzvunun telef olması daha büyük bir zarar olduğundan, hafif olan zarar işlenmek suretiyle, zararın daha büyüğünden kaçınılmış olmaktadır. Hatta cumhur, aşırı açlığa maruz kalan bir kişinin leş veya domuz eti gibi haram bir şeyi yemesinin veya boğazına takılan bir yemeği geçirmek için yanında bulunan şarabı içmesinin farz olduğunu söylemişler ve bulduğu haram yiyecek ve içeceği kullanmadığından dolayı ölen kimsenin de Allah katında mes'ul olacağını belirtmişlerdir. ${ }^{119}$ Çünkü böyle bir durumda kişi kendi eliyle kendisini tehlikeye atmış olmaktadır ki, bu da Kur'ân nassıyla yasaklanmıştır. ${ }^{120}$

Kur'ân'da dört farklı ayette haram kılınan gıdalar sayıldıktan sonra, zaruret durumunda bunları yemenin mubah hâle geleceği sarih bir şekilde beyan edilmiştir. ${ }^{121}$ Mesela Bakara sûresinde Yüce Allah, leş, kan, domuz eti ve Allah'tan başkası adına kesilen hayvanın etinin haram kılındığını bildirdik-

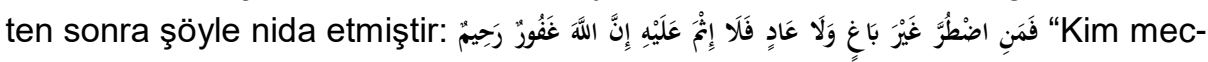
bur kalırsa başkasının hakkına tecavüz etmemek ve zaruret miktarını geçmemek şartıyla bunlardan yemesinde günah yoktur. Allah gafurdur, rahimdir."122 Mâide sûresinde de haram yiyecekler sayıldıktan sonra şöyle buyrul-

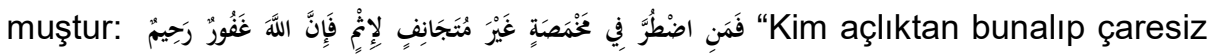
kalırsa, günaha meyletmeksizin haram olan etlerden yiyebilir. Çünkü Allah gafurdur, rahimdir."123 Bu ayetlerden yola çıkan fakihler, bu meseleyi şu şekil-

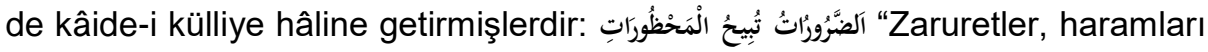
mubah kılar."124

Yukarıdaki ayetlerde, haramlardan istifadenin günah olmaması için kayıtları getirilerek zaruret hâlinde bile haramlardan istifade etmede belli sınırlar çizilmiştir. Buna göre haramı yemeye mecbur kalan kimse, başkasının hakkına tecavüz etmeyecek, lezzet alma maksadı gütmeyecek ve karnını doyurmadan sadece içine düştüğü zaruret hâlinden kurtulacak kadar haramdan yiyecektir. Ayetlerdeki bu kayıtlardan yola çıkan fukaha zaruretle ilgili olarak şöyle bir fıkıh kâidesi oluşturmuşlardır: الضَّرُوراتُ تُقَدَّرُ بِقَدِرِها "Zaru-

\footnotetext{
119 Vehbe Zühayli, el-Fıkhu'l-Islâmî ve edilletuhû, (Dimeşk: Dâru'l-fikr, 1985), 4: 154.

120 el-Bakara 2/195.

121 Bkz. el-Bakara 2/173; el-Mâide 5/3; el-En'âm 6/145; en-Nahl 16/115.

122 el-Bakara 2/173.

123 el-Mâide 5/3.

124 Ali Haydar Efendi, Dürerü'l-hukkâm şerhu mecelleti'l-ahkâm, çev. Fehmi el-Hüseynî, (Beyrut: Dâru'l-cîl, 2003), 1: 37.
} 
retler, kendi miktarınca takdir olunur." ${ }^{25}$ Buradan da anlaşılmaktadır ki muzdar durumda kalan kimse, zaruret miktarını aşmadan haramdan faydalanmalıdır. Haramı kullanmadaki maksat, zaruret halini gidermek olduğuna göre, zaruret hali ortadan kalktıktan sonra haramdan istifade etmek de helâl olmayacaktır. Dolayısıyla zaruret kapısını kapamak doğru olmadığı gibi, bu kapıyı sonuna kadar açmak ve böylece ruhsatları kalıcı bir şekilde kullanmak da doğru değildir. ${ }^{126}$

Ayrıca zaruret hâlinin oluşması için bazı şartlar ileri sürülmüş ve ancak bu şartların mevcudiyeti durumunda haramlardan istifadenin mubah hale geleceği belirtilmiştir. Buna göre haramı mubah kılan zaruret halinin oluşması için öncelikle ortada bir tehlike ve zarar durumunun bulunması gerekir. Diğer bir ifadeyle haram bir gıdayı yemeyle veya haram bir fiili işlemeyle yüz yüze gelen şahıs, söz konusu haramı işlemediği takdirde nefsinin veya bir uzvunun telefinden korkmalıdır. İkinci olarak kişinin maruz kaldığı tehlike filhâl mevcud olmalıdır. Ancak zann-ı galible helâkinden korkan bir kimsenin de helâk olma derecesine gelmeyi beklemeden haramlardan istifade edebileceği ifade edilmiştir. Üçüncü olarak, tehlike kaçınılmaz olmalıdır. Yani muzdar durumdaki bir kimsenin, içinde bulunduğu tehlikeli durumdan kurtulmak için haramı işlemekten başka bir çaresi bulunmamalıdır. Dördüncü olarak tehlikeye bir ölçü getirme adına onun mülci olması gerektiği ifade edilmiştir. Buna göre hayatî bir tehlike söz konusu olmadığı müddetçe, maruz kalınması muhtemel küçük zararlardan dolayı haramların çiğnenmesi mubah görülmemiştir. Beşinci olarak muzdar durumda kalan kimsenin, meşru ve helâl yollarla içine düştüğü ızdırar halinden kurtulabilme imkânı olmamalıdır. Son olarak da şahsın, tehlikenin bulunduğuna dair kesin kanaatinin veya zann-ı galibinin olması gerektiği ifade edilmiştir. ${ }^{127}$

İslâm hukukunda, zaruretlerin haramları mubah kılacağı önemli bir kâide olsa da bu kâidenin bazı istisnaları vardır. Yani zaruret hali her haramı mubah kılmaz. Mesela açlıktan ölmek üzere olan bir kimse, bir insanı öldürerek onun etini yiyemez. Aynı şekilde ölümle tehdit edilen bir insanın zina işlemesi mubah hale gelmez. Yine bir kimse ne kadar muzdar durumda bulunur-

125 Ali Haydar, Dürerü'l-hukkâm, 1: 38.

126 Erdoğan, İslâm İlmihali, 654.

127 Bkz. Mustafa Baktır, İslâm Hukukunda Zaruret Hali, (Ankara: Akçağ Yay.) 231-250; Zühaylî, Nazariyyetü'd-darûreti'ş-şer'iyye, 68-71.

ÇÜiFD, 2018, cilt: 18, sayı: 1, ss. 597-633 
sa bulunsun, masum bir insanın canına kıyamaz. O halde, "Zaruretler, yasakları mubah kılar." prensibini umumî manası üzerine anlamak doğru değildir. ${ }^{128}$

Aslında zaruretlerin haramları mubah kılması, İslâm'ın getirdiği "kolaylık" ve "güçlüğün kaldırılması" prensiplerinin bir gereğidir. Aşağıdaki âyet ve hadislerde bu prensip açıkça ortaya konmuştur: "Allah sizin hakkınızda kolaylık ister, zorluk istemez."129; "Din konusunda, size hiçbir zorluk da yüklememiştir."130; "Allah size güçlük çıkarmak istemez, fakat şükredesiniz diye sizi temizleyip arındırmak ve size olan nimetlerini tamama erdirmek ister." ${ }^{131}$; "Şüphesiz bu din kolaylık dinidir. Her kim dini zorlaştırırsa din ona galip gelir."132

İslâm, vaz' ettiği bütün hükümlerinde bu prensiplere riayet etmiştir. Sözgelimi Allah Teâlâ kullarına kolaylık olması açısından pek çok ruhsat koymuştur. İşte zaruret hallerinde de kullar için büyük bir meşakkat ve güçlük bulunduğundan, bu güçlüğün kaldırılması adına mükellefler için bazı ekstra kolaylıklar getirilmiştir.

\section{Haramlarda Taabbudilik Esastır}

Öncelikli olarak kıyas ictihadının yürütülebilmesi sonra da teşrîin daha iyi anlaşılması, nassların doğru yorumlanabilmesi ve diğer içtihat çeşitlerine yardımcı olması için hükümlerin konuluş gerekçelerinin ve amaçlarının tespit edilmesi usulcülerin öncelikli hedeflerinden birisini oluşturmuştur. Buna göre hükümler, illetlerinin bilinip bilinmemesine göre taabbudî ve ta'lili olmak üzere ikiye ayrılmış; illeti tespit edilebilenler muallel (mâ'kulu'l-mânâ), tespit edilemeyenler ise taabbudî hüküm olarak isimlendirilmiştir. Daha geniş manasıyla, aklın alanına girmeyen, illetleri bilinemeyen, Şâri'in kendileriyle neyi amaçladığı gizli kalmış ve faydası da insanlar tarafından tam olarak kavranamayan hükümlere taabbudî hükümler denilmiştir. ${ }^{133}$ Şer'î hükümlerin böyle bir taksime tâbi tutulmasının temel sebebi, içtihat sahasını tespit etmektir. Zira illeti

\footnotetext{
128 Konunun tafsilatı için bkz. Abdülkerim Zeydan, "İslâm Hukukunda Zaruret Hali”, çev. Hayrettin Karaman, İslâm'ın Işı̆̆ında Günün Meseleleri içinde, (İstanbul: İz Yayıncılık, 2001), 235-295.

129 el-Bakara 2/185.

130 el-Hacc 22/78.

131 el-Mâide 5/6.

132 Buharî, "İman”, 29; Nesâî, "İman”, 28.

133 İzz b. Abdisselâm, Kavâidu'l-ahkâm, 1: 18.
} 
tespit edilen nassların hükmü, kendileriyle aynı illeti taşıyan başka meselelere de verilirken, taabbudî hükümlerde böyle bir kıyasa gidilemez. ${ }^{134}$

Şer'î hükümler, temelde ibadât ve muamelât olmak üzere ikiye ayrılmış, ibadetler alanında taabbudîliğin, muamelat sahasında ise ta'lilin esas olduğu ifade edilmiştir. Diğer bir ifadeyle akıl, muamelât kısmına dâhil olan hükümlerin vaz' edilişindeki sebep ve illeti kavrayabilirken, ibadetlerde gözetilen manaları her zaman idrak edemeyebilir. Taabbudî hükümler herhangi bir maslahat ve fayda elde etmek için değil, Allah'ın emrini yerine getirmek ve O'nu yüceltmek maksadıyla yerine getirilirler. İstikra' yöntemine dayanarak böyle genel bir taksim yapılması doğru olsa da ibadetler sahasında muallel bazı hükümlerin, muamelat sahasında ise bazı taabbudî hükümler bulunduğu da bir gerçektir. ${ }^{135}$

Fakat şunu da ifade etmek gerekir ki taabbudî hükümlerle muallel hükümlerin sınırını kesin hatlarla ayırmak her zaman mümkün olmamaktadır. Ayrıca konuyla ilgili fukaha arasında intilâfların bulunduğu da bir gerçektir. Hatta denebilir ki füruattaki ihtilafların önemli bir kısmı, hükümlerin taabbudî veya muallel kabul edilmesindeki ve muallel kabul edilen hükümlerin de illetini tespit etmedeki farklılıktan kaynaklanmaktadır.

Haramlarla ilgili hükümlerin tespitinde de konuyla ilgili farklı yaklaşımlar bulunmaktadır. "İskâr" vasfının illet olarak görülmesinden hareketle sarhoşluk verici her içkiye haram hükmünün verilmesi veya hakkında nasslarda bir açıklama yer almayan bazı hayvanların hükmünü tespit etmede kıyas delilinin kullanılması ya da habîslik sıfatının bir illet olmasından hareketle bu illeti taşıyan hayvanların haram kılınması örneklerinde olduğu gibi haramlarla ilgili hükümlerin bir kısmının muallel olduğu söylenebilirse de; haramlar sahasında genel manada taabbudîliğin hâkim olduğu pek çok araştırmacı tarafından ifade edilmiştir. ${ }^{136}$ Mesela, domuzun, leşin, kanın, Allah'tan başkası adına kesilen veya üzerine besmele çekilmeyen hayvanın haram olmasının sebebi, bunlarla ilgili yasaklayıcı ayetlerin bulunmasıdır. ${ }^{137}$ Bunların haramlık illeti bilinemediğinden dolayı, daha başka gıdaları da bunlara kıyas yaparak haram kılmak doğru değildir. Aynı şekilde illetin zail olması gerekçe gösterilerek,

134 Muhammed Mustafa eş-Şelebî, Ta'lilü'l-ahkâm, (Beyrut: Dâru'n-nehdati'l-Arabiyye, 1981), 229.

135 İzz b. Abdisselâm, Kavâidu'l-ahkâm, 1: 18; Şâtıbî, el-Muvâfakât, 2: 525.

136 Mehmet Erdoğan, İslâm Hukukunda Ahkâmın Değişmesi, (İstanbul: Marmara Üniversitesi İlahiyat Vakfı Yay., 4. baskı, 2000), 130; Abdullah Kahraman, "Gıda Ürünlerinde Helâl ve Haramı Belirleme Yöntemi", 464-465.

137 Bkz. el-Mâide 5/3; el-En'âm 6/121, 145; en-Nahl 16/115. 
haram olan bu gıdaların haramlığının sona ermesi de mümkün değildir. Çünkü bunların haramlık illeti harici bir mana değil, bizzat Şarî Teâlâ'nın nehyidir. Haram kılmada esas olanın taabbudîlik olduğunu ifade eden Mehmet Erdoğan, "Cennette iken $\mathrm{Hz}$. Âdem ve Havva'ya ağacın yasaklanmasının illeti ne idiyse, bunlardaki illet de odur." diyerek haramların illet ve sebebinin emr-i ilahi olduğuna dikkat çekmiştir. ${ }^{138}$

Hadislerde yasaklanan, erkeklerin altın kullanması ve ipek giymesi, altın ve gümüş kapların istimali, süt akrabalarla evlenmek, dövme yaptırmak, saça saç eklemek, kaş aldırmak, sihir ve büyü ile meşgul olmak, evde köpek beslemek, resim yapmak gibi fiillerin haram kılınmasını da taabbudîlik ile açıklamak mümkündür. Her ne kadar söz konusu fillerin yasaklanmasıyla ilgili bir kısım sebep ve hikmetler üzerinde durulsa da bunlar gerçek illet değildir. Bu konudaki illet, Allah ve Resûlü'nün nehyidir. Fakat hırsızlık yapmak, adam öldürmek, zina yapmak, yetim malı yemek, içki içmek ve faizli muamele yapmak gibi mefsedet ve zararın daha belirgin olduğu haramlar da vardır. Fakat netice itibarılya söz konusu filllerin nehiy gerekçesi de emr-i ilâhiye dayanmaktadır.

Helâl ve haramlar ancak vahiyle bilinebileceğinden bunların tespitinde re'y ve ictihadın yeri yoktur. Bu açıdan daha önce de ifade edildiği üzere selef uleması, hakkında kesin bir nass bulunmayan konulara haram demekten kaçınmıs, bunun yerine, "mekruh", "hoş görmem", "sevimsiz" gibi ifadeler kullanmışlardır. Helâl ve haramlar içtihatla belirlenemeyeceğine göre, bunların zamanla değişmesi de söz konusu değildir. ${ }^{139}$

\section{Helâl Dairesi Harama İhtiyaç Bırakmayacak Kadar Geniştir}

Bütün mülkün sahibi olan ve dilediğini yapma kudretine sahip Yüce Allah, hiçbir ameli yapmakla zorunlu tutulamaz. Cenâb-ı Hak dileseydi, insana faydalı olan ve onun intiyaç duyacağı yiyecek ve içecekleri haram kılabilir ve böylece insanı meşakkat ve sıkıntıya maruz bırakabilirdi. Fakat her işinde pek çok hikmet ve maslahat bulunan Allah Teâlâ böyle yapmamış, haram dairesini oldukça sınırı tutmuş hatta bunun yanında ya tamamen insana zararlı olan ya da zararı faydasından daha çok bulunan şeyleri insana haram kılmıştır. Mesela ayetlerde alkol ve domuz etinin "rics" olduğu ifade edilerek onların zararlı

138 Erdoğan, Ahkâmın Değişmesi, 130.

139 Erdoğan, Ahkâmın Değişmesi, 130. 
olduğuna işaret edilmiş, ${ }^{140}$ aynı şekilde içkinin zararlarının faydalarından daha fazla olduğu belirtilmiştir. ${ }^{141}$

Yüce Allah kâinatı insanın emrine âmâde kılmış, yeryüzündeki her şeyi insan için yaratmış ve insanı da yeryüzünün halifesi kılarak eşya ve hâdiseler üzerinde ona tasarruf yetkisi vermiştir. Bu açıdan yukarıda da belirtildiği üzere haram olduğuna dair açık bir nass bulunmayan bütün nimetler insan için helâldir ve bu helâller haramlara muhtaç bırakmayacak ölçüde insanın intiyacını karşılamaya kâfidir. Zira Allah hiçbir şeyi haram kılmamıştır ki onun yerine başka bir helâl koymamış olsun. Haram kılınan fiil ve nesneler düşünüldüğünde bunların her birinin yerini tutacak helâl alternatiflerinin bulunduğu görülecektir. Örnek vermek gerekirse, içki haram kılınmış fakat ona bedel su, süt, bal, ayran ve çeşit çeşit meyve suları gibi pek çok lezzetli içecek helâl kılınmış; ipeğin haram kılınmasına mukabil yün, pamuk ve ketenden mamul elbiseler helâl kılınmış; zina haram olmasına rağmen nikâh yoluyla bir araya gelmek meşru kılınmış; bazı hayvanların etinin yenmesi yasaklanırken, evcil veya yabanî pek çok hayvan eti mubah kılınmış ve yine faizin yerine birçok alış-veriş çeşidi ve ticaret meşru kılınmıştır. ${ }^{142}$ Yüce Allah rahmet ve şefkatinin bir eseri olarak helâl dairesini harama nazaran çok daha geniş tutarak, kullarını haramları irtikâp etmeye muhtaç bırakmamıştır.

Helâl dairesinin harama intiyaç bırakmayacak ölçüde geniş olmasına ve haramların da azlığına rağmen hâlâ bir mü'min helâl dairesiyle iktifa etmeyerek, ölçü ve sınır tanımayarak elini harama uzatacak olursa, haddini aşmış ve dolayısıyla da Allah'ın gazabını hak etmiş olacaktır. İşte Yüce Allah, "Size verdiğimiz rızıkların en hoş ve temiz olanlarından yiyin. Ama sakın bu hususta haddinizi aşmayın. Yoksa gazabım tepenize iniverir. Kimi de gazabım çarparsa artık o uçuruma düşmüştür."143 sözüyle kullarını harama girmeme ve dolayısıyla gazab-ı ilahiye maruz kalmama hususunda ikaz etmiştir.

\footnotetext{
140 el-Mâide 5/90; el-En'âm 6/145.

141 el-Bakara 2/219.

142 Karadâvî, el-Halâl ve'l-harâm, 32-33.

143 et-Tâhâ 20/81.
} 


\section{Sonuç}

Bu çalışmada, helâl ve haram konusuyla ilgili on bir farklı kâide ve ilke ele alınmış ve bunların, delilleri, anlamları ve cüz'i hükümler açısından önemleri izah edilmiştir. Bütün bu izah ve açıklamalar neticesinde söz konusu kaide ve ilkelerle ilgili şu neticelere ulaşılmıştır:

Hükümlerin kaynağı, hukuk felsefesi ve hukuk usulünün önemli konularından birisidir. Farklı hukuk sistemleri bununla ilgili başta akıl ve örf olmak üzere değişik kaynaklar üzerinde dursalar da Kur'ân-ı Kerim, hüküm koyma yetkisinin Allah'a ait olduğu hususu üzerinde hassasiyetle durmuştur. Dolayısıyla helâl ve haram kılma yetkisi de yalnızca Allah'a aittir. Yasakların (haram/tahrimen mekruh) bulunup çıkarılacağı temel kaynak, Kitap ve Sünnet'tir. Nelerin helâl olduğunu anlamak için böyle bir araştırma yapmaya gerek yoktur. Zira "Eşyada asıl olan ibahadır." kâidesi gereğince herhangi bir fiilin haramlığına dair şer'î bir delil bulunmadığı sürece, onun helâl olduğuna hükmedilir. Buradan hareketle helâllerin haramlara nispetle çok daha fazla olduğu ve insanı haramlara muhtaç bırakmayacağı da bir gerçektir.

İslâm dininin getirmiş olduğu bütün düzenlemeler temel itibarıyla maslahatların elde edilmesi ve mefsedetlerin uzaklaştırılmasına yöneliktir. Şeriat hakkındaki bu genel ilke, helâl ve haramlar alanında da geçerlidir. Yani istikra metoduyla bu konudaki hükümler incelendiğinde, kullar açısından fayda ve maslahat içeren fiillerin helâl, neticesi itibarıyla zarar ve mefsedete yol açan fiillerin ise haram kılındığı görülecektir. Bu durum haramların taabbudî olmasına mâni değildir. Yani domuz eti yemek, altın kap kullanmak gibi tek tek haramlar ele alındığında, bunların yasaklanmasının asıl sebebinin Allah'ın emri olduğu neticesine ulaşılacaktır.

Öte yandan hangi fiillerin haram olduğu Kur'ân ve Sünnet'te açıkça belirtilmiş olsa da bunların arasında kalan bazı şüpheli alanların bulunduğu da yine $\mathrm{Hz}$. Peygamber tarafından dile getirilen hususlardandır. Bu tür şüpheli fiillerin haram olma intimali de bulunduğundan, Hz. Peygamber tarafından onların terk edilmesi tavsiye edilmiştir. Aynı şekilde helâl ve haramın birlikte olduğu ve bunlardan birisini tercih zorunluluğunun bulunduğu durumlarda, söz konusu fiilin haram kabul edilerek ondan uzak durulması gerektiği, bu konuda üzerinde durulan önemli bir kâidedir.

Haramların belirli bir yeri yurdu olmadığı gibi, onların belli şahıslara tahsisi de söz konusu değildir. Yani bir insan nerede yaşarsa yaşasın ve onun kimliği her ne olursa olsun, helâl ve haram hükümlerine muhataptır. Haram hükümleri objektif olduğu için, onların ne belirli şahıslara göre, ne de bir şah- 
sın niyetine göre değişmesi söz konusu olamaz. Farklı bir ifadeyle niyetin iyi olmasının haramlık hükmüne bir etkisi yoktur. Haramlık hükmünün kalkmasının tek istisnası, zaruretlerdir. Kolaylık gösterilmesi ve meşakkatin kaldırıması İslâm'ın önemli ilkelerinden birisi olduğu için, zaruretin bulunduğu durumlarda, haramlar muvakkaten ve sınırlı olarak mubaha dönüşecektir.

İslâm, haramların terkine büyük önem verdiğinden, ona götüren vesileleri de aynı şekilde haram kabul etmiştir. Fıkıh, bir fiilin şekil ve suretinden ziyade, mana ve maksadına bakmış ve buna göre hüküm vermiştir. Buna göre mahiyeti itibarıyla herhangi bir mefsedet içermeyen fakat mefsedete götüren sebep ve vesileler de yasaklanmıştır. Aynı şekilde meşru görünümlü bir kısım hilelerle haramlardan kurtulmaya çalışmak ve haramlardan kaçmak için hileye başvurmak da caiz değildir.

\section{Kaynakça}

Ahmed b. Hanbel. el-Müsned. thk. Şuayb Arnavut. Beyrut: Müessesetü'rrisâle, 1999.

Ali Haydar Efendi. Dürerü'l-hukkâm şerhu mecelleti'l-ahkâm. çev. Fehmi elHüseynî. Beyrut: Dâru'l-cîl, 2003.

Bâhuseyn, Yakub b. Abdilvehhâb. el-Mufassal fi'l-kavâidi'l-fıkhiyye. Riyâd: Dâru't-tedmuriyye, 2011.

Baktır, Mustafa. İslâm Hukukunda Zaruret Hali. Ankara: Akçağ Yayınları.

Beyhakî, Ebû Bekr Ahmed b. el-Hüseyin b. Ali. es-Sünenü'l-kübrâ. Haydarabad: Dâiretü'l-maârifi'l-Osmaniyye, 1344.

Buharî, Ebû Abdullah Muhammed b. İsmail. el-Câmiu's-Sahih. Beyrut: Dâru'lkütübi'l-ilmiyye, 1994.

Burhânî, Muhammed Hişâm. Seddü'z-zerâi' fi'ş-şerîati'l-İslâmiyye. Dimeşk: Dâru'l-fikr, 1995.

Bûtî, Said Ramazan. Davâbitu'l-maslaha fi'ş-şeriati'l-Islâmiyye. Beyrut: Müessesetü'r-risâle, 1982.

Cessâs, Ebû Bekir Ahmed b. Ali. Ahkâmu'l-Kur'ân. thk. Abdüsselam Muhammed Ali Şâhin. Beyrut: Dâru'l-kütübi'l-ilmiyye, 1994.

Cevizci, Ahmet. Felsefe Sözlüğü. İstanbul, Paradigma Yayınları, 1999.

Cürcânî, Ali b. Muhammed es-Seyyid eş-Şerif. Ta'rifât. thk. İbrahim el-Ebyârî. Beyrut: Dâru'l-kütübi'l-Arabî, 1405; Beyrut: Dâru'l-kütübi'l-ilmiyye, 1983. 
Çelebi, İlyas. "Hüsün-Kubuh". Türkiye Diyanet Vakfı Islâm Ansiklopedisi. 19: 59-63. İstanbul: TDV Yayınları, 1999.

Darakutnî, Ebû'l-Hüseyn Ali b. Ömer. Sünen. thk. Abdullah Hâşim el-Yemânî. Beyrut: Dâru'l-ma'rife, 1966.

Dönmez, İbrahim Kâfi. "Sedd-i Zerâi'. Türkiye Diyanet Vakfı İslâm Ansiklopedisi. 36: 277-282. İstanbul: TDV Yayınları, 2009.

Ebû Dâvud, Süleyman b. el-Eş'as es-Sicistanî. Sünenü Ebî Dâvud. Beyrut: Dâru'l-kütübi'l-Arabî.

Ebû Zehre, Muhammed. Usûlü'l-fıkh. Kahire: Dâru'l-fikri'l-Arabî.

Erdoğan, Mehmet. İslâm Hukukunda Ahkâmın Değişmesi. Marmara Üniversitesi İstanbul: Illahiyat Vakfı Yay., 4. baskı, 2000.

Erdoğan, Mehmet v.dğr. İslâm İlmihali. İstanbul: Marmara İlahiyat Vakfı, 2006.

Fahruddin er-Râzî, Muhammed b. Ömer. el-Mahsûl. Müessesetü'r-risâle, 1997.

Gazzâlî, Ebû Hâmid Muhammed b. Muhammed. İhyâu ulûmi'd-dîn. Beyrut: Dâru'l-mâ'rife.

Gazzî, Muhammed Sıddıkî b. Ahmed. Mevsûatü'l-kavâidi'l-fıkhiyye. Beyrut: Müessesetü'r-risâle, 2003.

Hâkim en-Nisâburî, Ebû Abdullah Muhammed b. Abdullah. el-Müstedrek ala's-Sahihayn. thk. Mustafa Abdülkadir Ata. Beyrut: Dâru'l-kütübi'lilmiyye, 1990.

Hammâd, Nezih. el-Mevâddü'l-muharreme ve'n-necisât fi'l-gızâi ve'd-devâi beyne'n-nazariyyeti ve't-tatbîk. Dimeşk: Dâru'l-kalem, 2. baskı, 2011.

İbn Abdisselâm, İzzüddin Abdülaziz b. Abdisselam b. Ebi'l-Kasım b. Hasan. Kavâidü'l-ahkâm fî mesâlihil'-enâm. thk. Mahmud b. et-Telâmîd eşŞenkîtî. Beyrut: Dâru'l-ma'rife.

İbn Âşûr, Muhammed Tâhir b. Âşûr. İslâm Hukuk Felsefesi. çev. Vecdi Akyüz ve Mehmet Erdoğan. İstanbul: Rağbet Yay., 2006.

İbn Kayyim el-Cevziyye. I'lâmü'l-muvakiîn an Rabbi'l-âlemîn. Beyrut: Dâru'lkütübi'l-ilmiyye, 1991.

İbn Mâce, Ebû Abdullah Muhammed b. Yezid el-Kazvinî. Sünenü İbn Mâce. thk. Muhammed Fuad Abdülbaki. Beyrut: Dâru'l-fikr.

İbn Manzûr, Muhammed b. Mükerrem b. Ali el-Ensârî. Lisânü'l-Arab. Beyrut: Dâru sâdır.

İbn Nüceym, Zeynüddin Zeyn b. İbrâhim b. Muhammed. el-Eşbâh ve'n-nezâir. thk. Abdülkerim el-Fudaylî. Beyrut: el-Mektebetü'l-asriyye, 2003. 
İbn Recep el-Hanbelî, Abdurrahman b. Ahmed b. Receb. Câmiu'l-ulûm ve’hikem. Beyrut: Dâru'I-ma'rife.

İsfehânî, Râgıb. el-Müfredât fî garîbi'l-Kur'ân. Dımeşk: Dâru'l-kalem, 1412.

İsnevî, Cemâlüddin Abdurrahman. Nihâyetu's-sûl şerhu Minhâci'l-vusûl. Beyrut: Dâru'l-kütübi'l-ilmiyye, 1999.

Kahraman, Abdullah. "Gıda Ürünlerinde Helâl ve Haramı Belirleme Yöntemi”. C. Ü. Illahiyat Fakültesi Dergisi. 16 (1): 458-478. 2012.

Kahraman, Abdullah. "İslâm'da Helâl ve Haramın Yeri ve Fıkıh Usulü Açısından Temellendirilmesi”, İslâm Hukuku Araştırmaları Dergisi, 2012, sy. 20, s. 43-69.

Karadâvî, Yusuf. el-Halâl ve'l-harâm fi'l-İslâm. Beyrut: el-Mektebetü'l-İslâmî, 5. baskı, 1994.

Karafî, Ahmed b. İdris b. Abdirrahim. Envâru'l-burûk fî envâi'l-furûk. thk. Halil el-Mansûr. Beyrut: Dâru'l-kütübi'l-ilmiyye, 1998.

Karafî, Ahmed b. İdris b. Abdirrahim. Şerhu tenkîhi'l-fusûl. Şeriketü't-tıbâati'lfenniyeti'l-müttehide, 1973.

Karaman, Hayrettin. Günlük Hayatımızda Helâller ve Haramlar. İstanbul: İz Yayıncılık, 2000.

Kızılkaya, Necmettin. "Hanefi Mezhebinde Kavâid İlmi ve Gelişimi”. Doktora Tezi, Selçuk Üniversitesi, 2011.

Köse, Saffet. "İslâm Hukukunda Kanuna Karşı Hile”. Doktora Tezi, Marmara Üniversitesi, 1993.

Musa, Kâmil. Ahkâmu'l-et'ime fi'l-İslâm. Beyrut: Müessesetü'r-risâle, 1986.

Muhammed, Cemil. Nazariyyetü'd-darûreti'ş-şer'iyye hudûduhâ ve davâbituhâ. Dâru'l-vefâ, 1988.

Musa, Yahya. “el-Kavâidu'l-fıkhiyye fi'ctimâil'halâli ve'l-haram ve ta'tbîkatuhâ'lmuâsıra”. Doktora Tezi, el-Câmiatu'l-Ürdüniyye, 2004.

Müslim, Ebû'I-Hüseyn Müslim b. el-Haccâc el-Neysâbûrî. Sahîhu Müslim. thk. Muhammed Fuad Abdülbaki. Beyrut: Dâru ihyâi't-türâsi'l-Arabî.

Müttakî, Alâuddin Ali b. Hüsamüddin. Kenzü'l-ummâl fî süneni'l-akvâli ve'lahvâl. thk. Bekrî Hayyânî. Müessesetü'r-risâle, 5. baskı, 1981.

Nesâî, Ebû Abdurrahman Ahmed b. Şuayb. Sünenü'n-Nesâî. thk. Abdülfettah Ebû Gudde. Haleb: Mektebetü'l-metbûati'l-İslâmiyye, 1986.

Pala, Ali İhsan. İslâm Hukukunda İhtiyat İlkesi. Ankara: Fecr Yayınları, 2009.

Rıza, Muhammed Reşid. Tefsiru'l-menâr. Kâhire: el-Hey'etü'l-Mısriyyeti'lâmmeti li'l-kütüb, 1990. 
Serahsî, Şemsüleimme Muhammed b. Ahmed. Kitâbu'l-mebsût. Beyrut: Dâru'l-ma'rife.

Seyyid, Mehmet. Medhal. Latinize: Selçuk Camcı. İzmir: Yeni Akademi Yayınları, 2010.

Suyûtî, Celâlüddin b. Ebî Bekr. el-Eşbâh ve'n-nezâir. Beyrut: Dâru'l-kütübi'lilmiyye, 1403.

Sübkî, Tacuddîn Abdülvehhab b. Ali b. Abdülkâfî. el-libhâc fî şerhi'l-minhâc alâ minhâci'l-vusûl ilâ ilmi'l-vusûl. Beyrut: Dâru'l-kütübi'l-ilmiyye, 1404.

Şafiî, Muhammed b. İdris. el-Ümm. Beyrut: Dâru'l-ma'rife, 1393.

Şâtıbî, İbrahim b. Musa b. Muhammed. el-Muvâfakât. thk. Ebu Ubeyde Meşhur b. Hasan Âli Süleyman. Dâru İbn Affân, 1997.

Şelebî, Muhammed Mustafa. Ta'lilü'l-ahkâm. Beyrut: Dâru'n-nehdati'lArabiyye, 1981.

Tirmizî, Ebû İsa Muhammed b. İsa. el-Câmiu's-sahîh süneni't-Tirmizî. thk. Ahmed Muhammed Şakir. Beyrut: Dâru ihyâi't-türâsi'l-Arabî.

Tûfî, Necmüddin Ebu'r-Rabi' Süleyman b. Abdilkavî b. Kerim. Şerhu muhtasari'r-ravda. thk. Abdullah b. Abdilmuhsin. Beyrut: Müessesetü'r-risâle, 1987.

Uğur, Seyyit Mehmet. “Fıkıh Usulünde Haram Kavramı”. Yüksek Lisans Tezi, Marmara Üniversitesi, 2009.

Zebidî, Murtaza Muhammed b. Muhammed. Tâcü'l-arûs min cevâhiri'l-kâmus. thk. Abdülhalim Tahâvî. Kuvety: et-Türâsü'l-Arabî, 2001.

Zerkeşî, Bedrüddin Muhammed b. Abdullah. el-Bahru'l-muhît fî usûli'l-fıkh. Dâru'l-kütüb, 1994.

Zerkeşî, Bedrüddin Muhammed b. Abdullah. el-Mensûr fi'l-kavâid, thk. Teysir Fâik Ahmed Muhammed. Kuveyt: Vizâretü'l-evkâf ve'ş-şuûni'lİslâmiyye.

Zeydan, Abdülkerim. "İslâm Hukukunda Zaruret Hali". çev. Hayrettin Karaman. İslâm'ın Işığında Günün Meseleleri içinde. İstanbul: İz Yayıncılık, 2001.

Zuhayli, Vehbe. Ahkâmu'I-mevâddi'n-necise ve'l-muharreme. Dimeşk: Dâru'lmektebî, 1997.

Zuhayli, Vehbe. Nazariyyetü'd-darûreti'ş-şer'iyye mukâranetün maa'l-kanûni'lvad'iyyi. Beyrut: Müessesetü'r-risâle, 1982.

Zuhayli, Vehbe. el-Fıkhu'l-İslâmî ve edilletuhû. Dımeşk: Dâru'l-fikr, 1985. 


\title{
Legal Maxims and Basic Principles Regarding Halals and Harams
}

Citation / (C- Çayıroğlu, Y. (2018). Legal Maxims and Basic Principles Regarding Halals and Harams, Çukurova University Journal of Faculty of Divinity, 18 (1), .

\begin{abstract}
Halals and harams form a substantial part of Islamic Shari'a. Accordingly, Islamic Shari'a has introduced a whole host of obligations and prohibitions not only about issues regarding belief and morality but also about subsections of Islamic jurisprudence such as worship, proper conduct, and punishments. As a result, without grasping the underlying logic about halal and haram and knowing fundamental tenets and principles regarding this issue, it would be impossible to have a proper understanding of current issues and reach at verdicts about them. This can be attributed to the close relationship between principles regarding halal and haram, infringement of the law, the sources of verdicts, motives and purposes, prudence, doubt, intent, loss, beneficence (maslahah), necessity, doing what God commands (taabbudî). Given all these, this article deals with the essential principles concerning halal and haram. The bases and principles that are addressed in this article are: Halal (lawfulness) and haram (illicit) power belongs to Allah; the default position on things are that it is lawful; in the benefits, lawfulness: in harms, unlawful (forbidden by religion, haram) is the norm; it is also forbidden to resort to cheating to legitimize the haram; opportunities that lead to haram are also haram; suspicious things must be abandoned to avoid haram; when halal and haram are together the illicit side of it is preferred; good intentions don't make the harams allowable; necessities do make the harams allowable; in harams, belonging to (the abandonment of forbidden acts just because Allah has ordered them) is the norm; halal circle is wide enough to leave no need for haram. The rules and principles regarding halal and haram were taken with a totalitarian approach, meaning the provisions in this regard have been taken in a holistic view. So it is not right to see that the rules and principles are limited to the ones listed here. With wider and deeper work to be done in this regard, it is of course possible to come up with new assumptions. But, as far as we can see, these are the main assumptions that the regulation books deal with.
\end{abstract}

Keywords- Halal, haram, necessity, loss, and fraud 